\title{
Future Projections of Antarctic Ice Shelf Melting Based on CMIP5 Scenarios ${ }^{\mathscr{O}}$
}

\author{
KAITLIN A. NAUGHTEN ${ }^{\mathrm{a}}$ \\ Climate Change Research Centre, University of New South Wales, and ARC Centre of Excellence for Climate System Science, Sydney, New \\ South Wales, and Antarctic Climate and Ecosystems Cooperative Research Centre, Hobart, Tasmania,
} Australia

\section{KATRIN J. MEISSNER}

Climate Change Research Centre, University of New South Wales, and ARC Centre of Excellence for Climate System Science, Sydney, New South Wales, Australia

\section{BENJAMIN K. GALTON-FENZI}

Australian Antarctic Division, and Antarctic Climate and Ecosystems Cooperative Research Centre, Hobart, Tasmania, Australia

\section{MATTHEW H. ENGLAND}

Climate Change Research Centre, University of New South Wales, and ARC Centre of Excellence for Climate System Science, Sydney, New South Wales, Australia

\author{
RALPH TIMMERMANN AND HARTMUT H. HELlMER \\ Alfred Wegener Institut, Bremerhaven, Germany
}

(Manuscript received 13 December 2017, in final form 27 March 2018)

\begin{abstract}
Basal melting of Antarctic ice shelves is expected to increase during the twenty-first century as the ocean warms, which will have consequences for ice sheet stability and global sea level rise. Here we present future projections of Antarctic ice shelf melting using the Finite Element Sea Ice/Ice-Shelf Ocean Model (FESOM) forced with atmospheric output from models from phase 5 of the Coupled Model Intercomparison Project (CMIP5). CMIP5 models are chosen based on their agreement with historical atmospheric reanalyses over the Southern Ocean; the bestperforming models are ACCESS 1.0 and the CMIP5 multimodel mean. Their output is bias-corrected for the representative concentration pathway (RCP) 4.5 and 8.5 scenarios. During the twenty-first-century simulations, total ice shelf basal mass loss increases by between $41 \%$ and $129 \%$. Every sector of Antarctica shows increased basal melting in every scenario, with the largest increases occurring in the Amundsen Sea. The main mechanism driving this melting is an increase in warm Circumpolar Deep Water on the Antarctic continental shelf. A reduction in wintertime sea ice formation simulated during the twenty-first century stratifies the water column, allowing a warm bottom layer to develop and intrude into ice shelf cavities. This effect may be overestimated in the Amundsen Sea because of a cold bias in the present-day simulation. Other consequences of weakened sea ice formation include freshening of High Salinity Shelf Water and warming of Antarctic Bottom Water. Furthermore, freshening around the Antarctic coast in our simulations causes the Antarctic Circumpolar Current to weaken and the Antarctic Coastal Current to strengthen.
\end{abstract}

Supplemental information related to this paper is available at the Journals Online website: https://doi.org/10.1175/JCLI-D-17-0854.s1.

${ }^{\text {a }}$ Current affiliation: British Antarctic Survey, Cambridge, United Kingdom.

Corresponding author: Kaitlin A. Naughten, kaight@bas.ac.uk 


\section{Introduction}

Phase 5 of the Coupled Model Intercomparison Project (CMIP5) (Taylor et al. 2012) comprises the most comprehensive suite of future climate projections to date. A variety of Earth system models, consisting of coupled components for the atmosphere, ocean, sea ice, and land surface, simulated future climate scenarios forced by standardized representative concentration pathways (RCPs). These range from RCP2.6, a "best-case scenario" where greenhouse gas concentrations stabilize by the mid-twenty-first century, to RCP8.5, a "business-asusual scenario" where concentrations continue to accelerate. Global emissions of greenhouse gases are currently following the RCP8.5 pathway (Sanford et al. 2014).

However, none of the Earth system models participating in CMIP5 included ice shelf interactions. Ice shelves, the floating extensions of the Antarctic Ice Sheet, buttress upstream glaciers and ultimately slow down sea level rise (Dupont and Alley 2005). The fate of ice shelves, and consequently the ice sheet, in the twenty-first century and beyond largely depends on the oceanic transport of heat into ice shelf cavities (the regions of the ocean between ice shelves and the seafloor) and resulting basal melting. Here we employ an ocean model, the Finite-Element Sea Ice/Ice-Shelf Ocean Model (FESOM; Wang et al. 2014; Danilov et al. 2015; Timmermann et al. 2012), which includes ice shelf cavities and simulates ice shelf basal melting and refreezing. FESOM is one of a number of ocean models that simulate ice shelf thermodynamics in this manner [see Dinniman et al. (2016) and references therein], but future projections with these models have so far been limited. By forcing FESOM with atmospheric output from the CMIP5 experiments, we obtain projections of ice shelf melt rates throughout the twenty-first century, as well as continental shelf water mass properties, sea ice processes, and Southern Ocean circulation.

FESOM has previously been used for future projections of ice shelf melting, forced with CMIP3 model output (the previous generation of climate projections to CMIP5). Timmermann and Hellmer (2013) presented FESOM simulations forced by output from the HadCM3 and ECHAM5 models, both present-day (the "20C" scenario) and future (the "E1" and "A1B" scenarios). The two CMIP3 models produced very different responses in FESOM, with the HadCM3 experiments exhibiting more realistic twentieth-century salinities on the continental shelf, higher present-day melt rates, and a much larger response to twenty-first-century warming, particularly for the Filchner-Ronne Ice Shelf (FRIS). Timmermann and Goeller (2017) repeated the HadCM3 A1B scenario, as well as an extended 20C control experiment, with FESOM coupled to a regional ice sheet model over the FRIS catchment. However, it is unclear to what extent these projections of ice shelf melting are affected by systematic biases in the CMIP3 models. Given the strong sensitivity to model choice shown by Timmermann and Hellmer (2013), as well as the known issues with CMIP simulations in the Southern Ocean region (see section 2), careful selection of CMIP5 models as well as bias correction of the atmospheric forcing fields seems warranted.

In this study, we select CMIP5 models based on their climatological agreement with atmospheric reanalyses over the Southern Ocean (section 2). We linearly biascorrect the CMIP5 output by applying anomalies in each variable over the twenty-first century, rather than their absolute values (section 3b). By forcing FESOM with two different RCPs and two choices of CMIP5 models, we assess the sensitivity of changes in ice shelf basal mass loss to the forcing scenario (section 4a). We investigate the mechanisms of warming in ice shelf cavities, with a particular focus on the Amundsen Sea (sections $4 \mathrm{c}$ and $4 \mathrm{~d}$ ). We also assess water mass properties, with respect to ice shelf cavities (section $4 b$ ) as well as dense water exported from the continental shelf (section 4e). Changes in large-scale Southern Ocean circulation (section $4 \mathrm{f}$ ) and sea ice (section $4 \mathrm{~g}$ ) are also discussed.

\section{Selection of CMIP5 models for future forcing}

CMIP5 models are well known to exhibit biases in the Southern Ocean region during their twentieth-century ("historical") simulations. For example, every single model analyzed by Sallée et al. (2013b) has a warm bias in Southern Ocean water masses, particularly near the surface. As a result, many CMIP5 models underestimate Antarctic sea ice extent, especially in summer (Turner et al. 2013). Furthermore, mixed layers in the Southern Ocean are too shallow year-round (Sallée et al. 2013a). Biases specific to the atmosphere have also been identified. In particular, the Southern Hemisphere westerly winds are consistently too far north in CMIP5 models, and frequently too weak (Bracegirdle et al. 2013; Swart and Fyfe 2012). This bias is concerning for our simulations, since water masses near the Antarctic continental shelf break may be particularly sensitive to the position and strength of the westerlies (Schmidtko et al. 2014; Spence et al. 2014, 2017).

Given these biases, forcing an ocean model such as FESOM with raw atmospheric CMIP5 output may be problematic and introduce additional uncertainties into our results. Furthermore, we spin up present-day FESOM simulations with the ERA-Interim atmospheric 
reanalysis (Dee et al. 2011). Switching from ERA-Interim to raw CMIP5 output would then introduce an undesirable step change in forcing at the beginning of each RCP.

To avoid these problems, rather than forcing FESOM with CMIP5 output directly, we instead force with CMIP5 anomalies during each RCP, added to the ERA-Interim present-day climatology. This method assumes that projected changes are not state dependent, that is, that the magnitude of future change does not depend on the simulated present-day climate. Projected changes in Southern Ocean temperature and salinity do not appear to be state dependent, as shown by Sallée et al. (2013b). However, no such analysis has been conducted for atmospheric variables. Therefore, to minimize the risk of state-dependent future changes distorting our forcing fields, we choose CMIP5 models with the smallest possible biases in their present-day simulations.

Here we evaluate the performance of CMIP5 models compared to the ERA-Interim reanalysis for 10 atmospheric variables over the Southern Ocean, in a monthly climatology calculated over 1992-2005. We follow the method of Gleckler et al. (2008), which uses the rootmean-square (rms) error as a metric of model skill. Rather than calculating the rms error over the entire globe, we restrict our analysis to the region $30^{\circ}-80^{\circ} \mathrm{S}$. It is important to note that ERA-Interim is not a perfect baseline for evaluation, as some biases are known to exist in its simulation of the Antarctic region. In particular, there are concerns regarding ERA-Interim's Southern Ocean cloud cover leading to a positive bias in summertime shortwave radiation (Naud et al. 2014). On the other hand, Nicolas and Bromwich (2011) showed that ERA-Interim provides the most realistic surface hydrological cycle of any atmospheric reanalysis over the Southern Ocean.

Models are selected based on availability of the 10 atmospheric variables required to force our FESOM configuration (see caption of Fig. 1), with monthly averages for the historical, RCP4.5, and RCP8.5 simulations. A total of 19 models fit these criteria (Fig. 1), and for each model we analyze a single ensemble member. We also apply the analysis to the multimodel mean (MMM) of the 19 models. For each model and each variable, we calculate the monthly climatology over 1992-2005 and linearly interpolate to the ERA-Interim grid. Following the equations of Gleckler et al. (2008), we calculate the rms error for each model and variable with respect to ERA-Interim over $30^{\circ}-80^{\circ} \mathrm{S}$, as well as the "relative error," which normalizes units across different variables. A relative error of 0.5 , for example, indicates that the given model has an rms error $50 \%$ higher than the median across all models (excluding the multimodel mean), for the given variable. Similarly, a

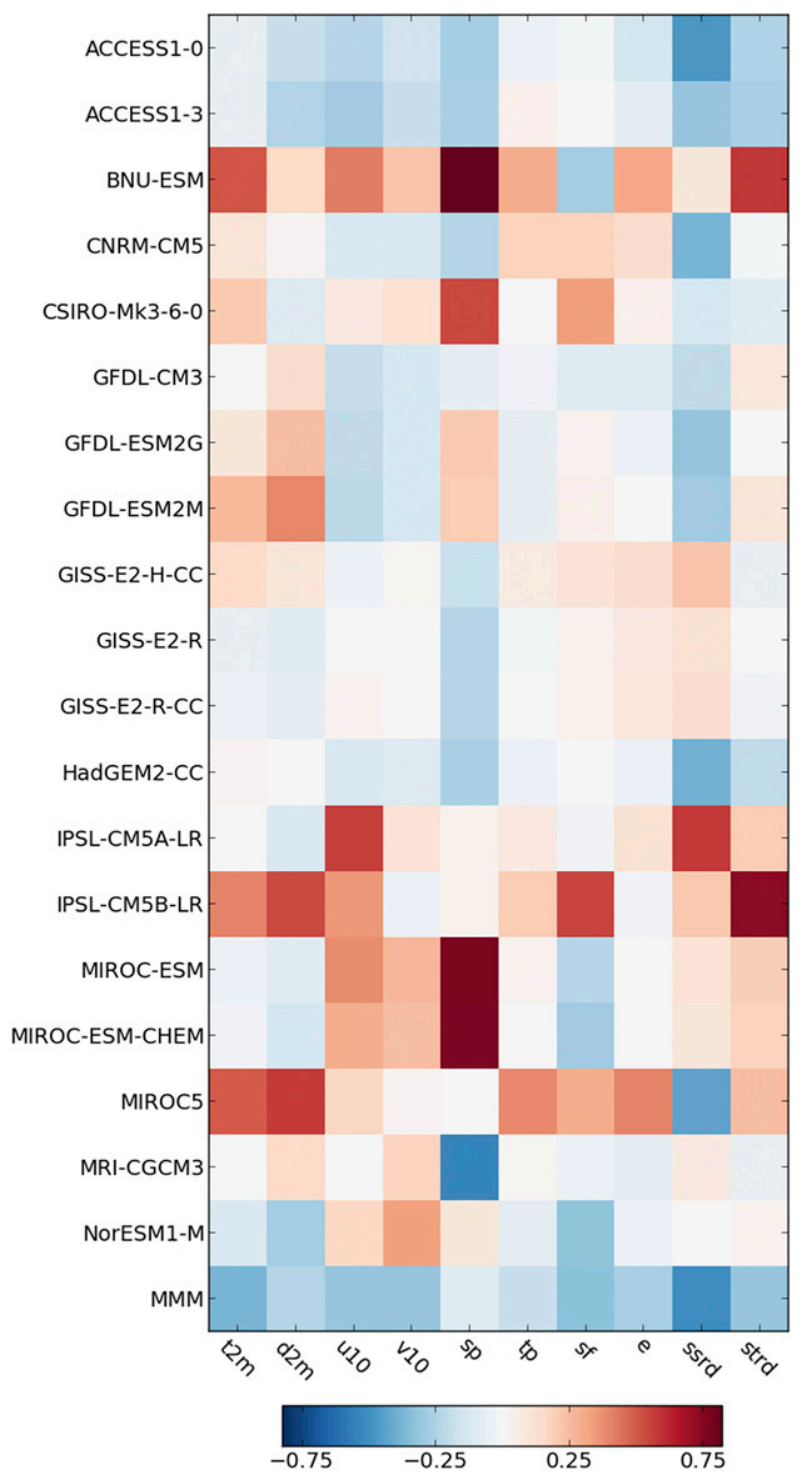

FIG. 1. Relative error (defined in section 2) for 19 CMIP5 models as well as the MMM, calculated over the 1992-2005 monthly climatology of each model's "historical" simulation, with respect to the ERA-Interim reanalysis over the same time period. Results are shown for nine atmospheric variables using ERA-Interim naming conventions: $\mathrm{t} 2 \mathrm{~m}$ (2-m air temperature), $\mathrm{d} 2 \mathrm{~m}$ (2-m dewpoint temperature), u10 and v10 (10-m winds), sp (surface pressure), tp (total precipitation), sf (snowfall), e (evaporation), ssrd (downward shortwave solar radiation), and strd (downward longwave solar radiation)

relative error of -0.5 indicates an rms error $50 \%$ lower than the median. Models in best agreement with ERAInterim will consistently have relative error scores that are the most strongly negative.

Figure 1 summarizes relative error for all models and variables in a portrait plot [as in Fig. 3 of Gleckler et al. (2008)], where the best-performing models are dominated 


\section{Horizontal resolution $(\mathrm{km})$}
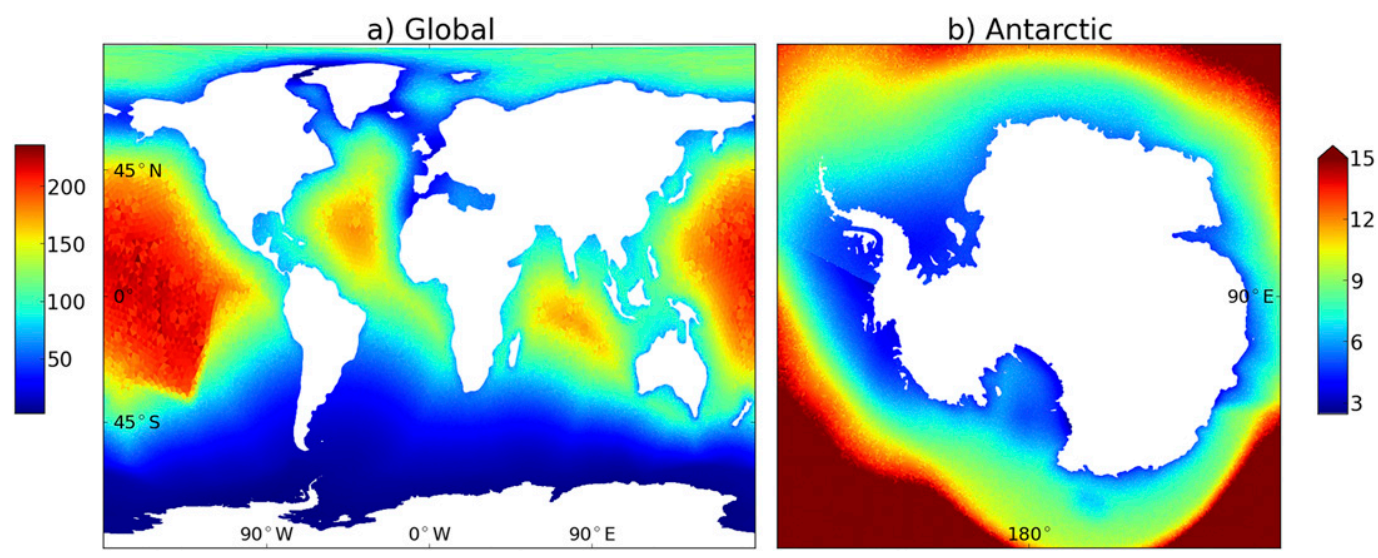

FIG. 2. Horizontal resolution $(\mathrm{km})$ in the FESOM mesh, defined as the square root of the area of each triangular element. (a) Global projection. (b) Circumpolar Antarctic projection; note the different color scale. Values above $15 \mathrm{~km}$ in (b) are not differentiated.

by blue squares. Notably, the multimodel mean has lower relative error than any of its component models for most variables. The tendency of individual model errors to cancel out in the multimodel mean was also discussed by Gleckler et al. (2008). However, the multimodel mean is not necessarily dynamically consistent or conservative. Among the individual models, ACCESS-1.0 generally has the lowest relative errors, with ACCESS-1.3 not far behind. This result agrees with Agosta et al. (2015), who found ACCESS-1.3 and ACCESS-1.0 to be the CMIP5 models in best agreement with atmospheric reanalyses over the Antarctic continent. Based on our analysis, we chose to construct two sets of future forcing fields for FESOM, using output from either the CMIP5 multimodel mean or ACCESS-1.0. The details of constructing these forcing fields are given in section $3 \mathrm{~b}$.

\section{Model description and experimental design}

Simulations are performed with FESOM, a global ocean model notable for its unstructured mesh. Triangular elements allow for variable horizontal resolution, so that small-scale processes such as sub-ice shelf circulation can be resolved, while coarse resolution elsewhere in the domain minimizes computational expense. The ocean component of FESOM is described by Wang et al. (2014), the sea ice component by Danilov et al. (2015), and the ice shelf component by Timmermann et al. (2012). Here we use the same configuration and parameter choices as in Naughten et al. (2018) but do not apply surface salinity restoring. Instead, as in previous publications with FESOM (Timmermann and Hellmer 2013), surface salt fluxes are corrected such that the global mean is zero.
Ice shelf thermodynamics (i.e., heat and salt fluxes at the ice shelf base due to melting and refreezing) are simulated by FESOM using the three-equation parameterization (Hellmer and Olbers 1989; Holland and Jenkins 1999), with velocity-dependent heat and salt transfer coefficients as detailed in Naughten et al. (2018). However, ice shelf geometry remains constant throughout all simulations, because any assumptions about changes in ice shelf draft would require coupling with an ice sheet model. This has recently been achieved with FESOM for the Filchner-Ronne region (Timmermann and Goeller 2017) but is not yet operational for the entire continent. It is likely that ice shelf geometry will indeed change throughout the twenty-first century, due to thinning and increased calving. Furthermore, FESOM does not consider the effects of tides, which are known to influence ice shelf melt rates (Makinson et al. 2011; Mueller et al. 2018), water mass exchanges at the ice shelf front (Arzeno et al. 2014), and transport of heat onto the continental shelf (Stewart et al. 2018).

\section{a. Resolution}

The FESOM mesh used in this study is the "highresolution" option from Naughten et al. (2018). It has coarsest resolution in the abyssal Pacific, Atlantic, and Indian Oceans, ranging from 150 to $225 \mathrm{~km}$ (Fig. 2a). Resolution is finer near coastlines, reaching approximately $75 \mathrm{~km}$ at low-latitude coastlines and $50 \mathrm{~km}$ for the Arctic and North Atlantic. The Southern Ocean contains the bulk of the computational nodes, with resolutions of $50 \mathrm{~km}$ or finer throughout the Antarctic Circumpolar Current (ACC). Resolution continues to refine south of the ACC and averages $5-7 \mathrm{~km}$ on the Antarctic continental shelf, including ice shelf cavities (Fig. 2b). The 
TABLE 1. Summary of simulations performed.

\begin{tabular}{lclc}
\hline \multicolumn{1}{c}{ Experiment } & \multicolumn{1}{c}{ Years } & \multicolumn{1}{c}{ Forcing } & Initialization \\
\hline CONTROL & 1992-2005, repeated 10 times & ERA-Interim & ECCO2 and NSIDC \\
RCP4.5 MMM & $2006-2100$ & RCP4.5 (multimodel mean) & Third repetition of CONTROL \\
RCP4.5 ACCESS & $2006-2100$ & RCP4.5 (ACCESS 1.0) & Third repetition of CONTROL \\
RCP8.5 MMM & $2006-2100$ & RCP8.5 (multimodel mean) & Third repetition of CONTROL \\
RCP8.5 ACCESS & $2006-2100$ & RCP8.5 (ACCESS 1.0) & Third repetition of CONTROL \\
\hline
\end{tabular}

Amundsen Sea has still finer resolution, of approximately $4 \mathrm{~km}$. Note that this is still insufficient to resolve mesoscale eddies around Antarctica, which are understood to be a major source of heat transport onto the continental shelf (Stewart and Thompson 2015; Stewart et al. 2018).

Vertical discretization comprises a hybrid sigma- $z$ coordinate system. Sigma coordinates, with 22 vertical levels, are employed south of the 2500-m isobath surrounding Antarctica. This region covers the entire continental shelf, all ice shelf cavities, and part of the continental slope. The rest of the domain uses $z$ coordinates, with 38 unequally spaced levels weighted toward the surface. All topographic data (bathymetry, ice shelf drafts, land-sea masks) are provided by the global 1-min Refined Topography dataset (RTopo-1.05; Timmermann et al. 2010).

\section{b. Initial conditions and forcing}

We use the same initial conditions as in Naughten et al. (2018). Temperature and salinity are provided by the ECCO2 reanalysis (Menemenlis et al. 2008; Wunsch et al. 2009) for January 1992 and extrapolated into ice shelf cavities. For the sea ice, initial conditions are based on the NOAA-NSIDC climate data record for passive microwave sea ice concentration (Meier et al. 2013) for January 1992. Wherever observed sea ice concentration exceeds 0.15 , the model is initialized with a concentration of 1 , ice thickness of $1 \mathrm{~m}$ (in the Antarctic) or $2 \mathrm{~m}$ (in the Arctic), and snow thickness of $0.2 \mathrm{~m}$. Initial sea ice velocity, ocean velocity, and sea surface height are set to zero.

Present-day atmospheric forcing is provided by the ERA-Interim reanalysis (Dee et al. 2011) and consists of 6-hourly fields for near-surface air temperature, dewpoint temperature, pressure, and winds and 12-hourly fields for incoming longwave and shortwave radiation, precipitation (split into rain and snow), and evaporation. We also apply an estimate of surface freshwater fluxes from iceberg melt, using the monthly climatology of Martin and Adcroft (2010).

Future simulations are forced using a combination of CMIP5 model output and ERA-Interim fields. The aim of this approach is twofold: to account for biases in the CMIP5 models' simulation of the mean climate state (as evaluated in section 2) and to maintain the presence of submonthly variability in the atmospheric forcing. Variability at the submonthly time scale, particularly for winds, has been shown to be important for the accurate simulation of Antarctic sea ice (Kim and Stössel 1998). However, the availability of CMIP5 atmospheric output at time scales finer than monthly averages is inconsistent. In fact, not a single CMIP5 model had submonthly output for all the variables and simulations we needed. For this reason, submonthly variability in our RCP forcing is derived from ERA-Interim, under the assumption that such variability will not change in an altered climate state.

The construction of the future forcing fields starts with monthly-averaged values for each variable. For each month of the RCP as simulated by a given CMIP5 model, we subtract that model's monthly climatology, calculated over the period 1992-2005 during the CMIP5 historical simulation. It is replaced by the ERA-Interim monthly climatology calculated over the same period. That is, we force FESOM with future anomalies as calculated by the CMIP5 model, rather than the absolute fields. Mean-state biases in the historical simulation as compared to ERAInterim are therefore corrected in a linear fashion.

Onto these monthly-averaged fields we superimpose variability on the 6- and 12-h time scales, as derived from ERA-Interim. For each 6- or 12-h time step in the period 1994-2005, we calculate the anomaly from the monthly mean (for the given year, not the monthly climatology) as simulated by ERA-Interim. These anomalies are added to the monthly fields described above, in a repeating 12-yr cycle throughout the RCP. The 12-yr period 1994-2005 was chosen (rather than 1992-2005 as for the climatology) so it is aligned with the 4-yr cycle of leap years. Since 2100 is not a leap year, the 12 -yr cycle is broken in 2100 and advanced by 1 year.

Freshwater fluxes from iceberg melting remain unchanged during the future simulations; the same monthly climatology is applied as for the present-day simulations. This design assumes that iceberg calving rates, as well as the spatial distribution of iceberg melting, will not change during the twenty-first century.

\section{c. Experiments}

We performed five simulations, summarized in Table 1. First, the present-day CONTROL simulation is forced 
solely with ERA-Interim, for which the forcing period 1992-2005 is repeated 10 times. The first two repetitions (i.e., 28 years) are considered spinup; after this time, ice shelf melt rates have stabilized. The third repetition of the forcing is treated as the genuine 1992-2005 period. RCP simulations (2006-2100) split off from the end of the third forcing repetition, but the control simulation continues parallel to these RCP experiments, to provide an estimate of model drift. Experiments RCP4.5 MMM and RCP8.5 MMM are forced with the RCP4.5 and RCP8.5 scenarios respectively, using output from the CMIP5 multimodel mean. The RCP4.5 ACCESS and RCP8.5 ACCESS simulations instead use output from the ACCESS 1.0 model.

For both RCPs, ACCESS 1.0 simulates greater twenty-first-century warming over the Southern Ocean than the multimodel mean. Therefore, in the results to follow, the RCP4.5 ACCESS simulation displays somewhat stronger changes than RCP4.5 MMM, and similarly for RCP8.5. Additionally, the atmospheric forcing derived from ACCESS 1.0 exhibits interannual and decadal variability that is absent from the multimodel mean, which is reflected in our FESOM simulations. The multimodel mean averages out the variability in each of the 19 component models, including interannual and decadal modes of variability, which typically occur out of phase between different CMIP5 simulations. This means that projected future changes in these modes of variability, such as El Niño events (Cai et al. 2014), which may affect the Amundsen Sea (Steig et al. 2012; Smith et al. 2017), also will not be captured by the MMM simulations.

\section{d. Present-day evaluation}

A comprehensive evaluation of this FESOM configuration was completed by Naughten et al. (2018). However, a brief summary of FESOM's performance and present-day biases around Antarctica is warranted.

First, simulated Antarctic sea ice extent agrees with observations in winter but melts back too much in summer. The simulated pattern of sea ice formation generally agrees with observations, but sea ice production is too strong in the Amundsen, Ross, and Weddell Seas, while the small coastal polynyas of the Australian sector are not well captured. Simulated transport of the Antarctic Circumpolar Current is slightly weaker than most recent observations.

With respect to ice shelf mass loss, our FESOM configuration underestimates total basal melting by nearly a factor of 2 compared to observational estimates. This is largely a regional bias confined to the Amundsen Sea, Bellingshausen Sea, and Australian sectors. By contrast, FESOM overestimates melting from the Amery and
Ross Ice Shelves. Simulated melt rates from the Filchner-Ronne Ice Shelf, the Larsen Ice Shelves, and the eastern Weddell sector generally agree with observations. However, the simulated circulation in the FRIS cavity is less realistic. A point of concern with this FESOM configuration is the amount of topographic smoothing necessary for numerical stability, and the effect this may have on the model's cavity geometry.

As previously mentioned, the only difference between the configuration of Naughten et al. (2018) and the configuration presented here is the treatment of surface salt fluxes (surface salinity restoring versus global correction). This difference has virtually no effect on total ice shelf mass loss from Antarctica. However, some regional differences are more pronounced. The presentday control simulation analyzed here shows higher melt rates in the Amundsen Sea sector (by up to $19 \%$ for Pine Island Ice Shelf) compared to the simulation of Naughten et al. (2018). This result suggests that surface salinity restoring contributes to the erosion of warm bottom water, a process discussed more fully in section $4 \mathrm{~d}$. The increased melting in the Amundsen Sea is offset by reduced melt rates downstream in the eastern Ross Sea, including the Sulzberger and Nickerson Ice Shelves.

\section{Results}

\section{a. Ice shelf basal mass loss}

In our RCP simulations, total basal mass loss from all Antarctic ice shelves increases by between $41 \%$ and $129 \%$ depending on the scenario. These percentages are calculated by comparing the 2091-2100 average (last 10 years of the RCPs) to the 1996-2005 average (10 years preceding the RCPs). The increased melting is more pronounced in the simulations forced with ACCESS 1.0 (67\% and $129 \%$ for RCP4.5 and RCP8.5, respectively) than in the simulations forced with the multimodel mean ( $41 \%$ and $90 \%$ ). This tendency can be attributed to the greater atmospheric warming in ACCESS 1.0, as noted in section $3 \mathrm{c}$.

Figure 3 partitions the increased mass loss into eight sectors: the Filchner-Ronne Ice Shelf, the eastern Weddell region (all ice shelves between FRIS and the Amery), the Amery Ice Shelf, the Australian sector (all ice shelves between the Amery and the Ross), the Ross Sea, the Amundsen Sea, the Bellingshausen Sea, and the Larsen Ice Shelves. The largest increases in ice shelf melting are seen in the Amundsen Sea, particularly in the RCP8.5 simulations where basal mass loss triples to quadruples. The regional processes causing this increased melting are discussed further in section $4 \mathrm{~d}$. The Ross Sea is the least affected sector in all four simulations, 


\section{Percent change in ice shelf basal mass loss by sector, 2091-2100 with respect to 1996-2005}

a) RCP $4.5 \mathrm{MMM}$

(40)

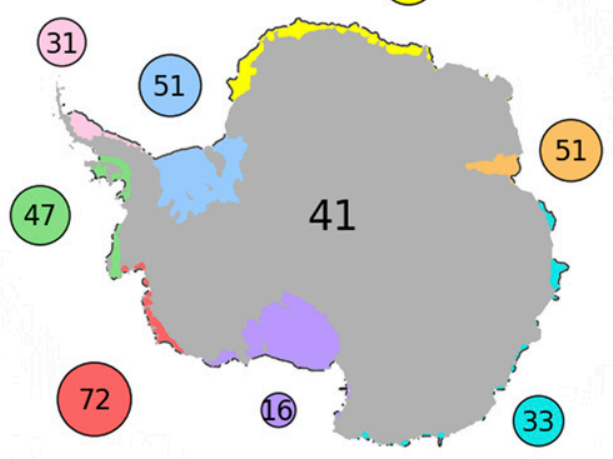

c) RCP 8.5 MMM

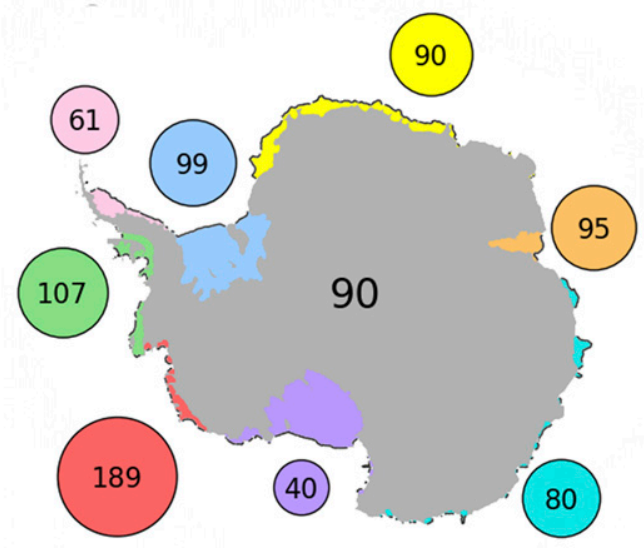

b) RCP 4.5 ACCESS

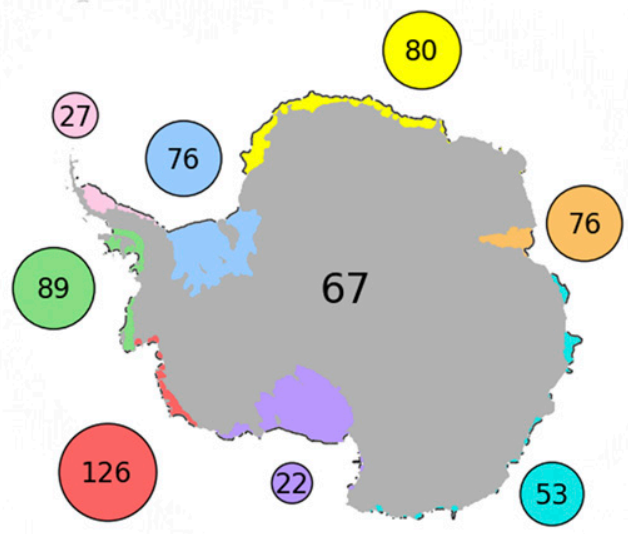

d) RCP 8.5 ACCESS

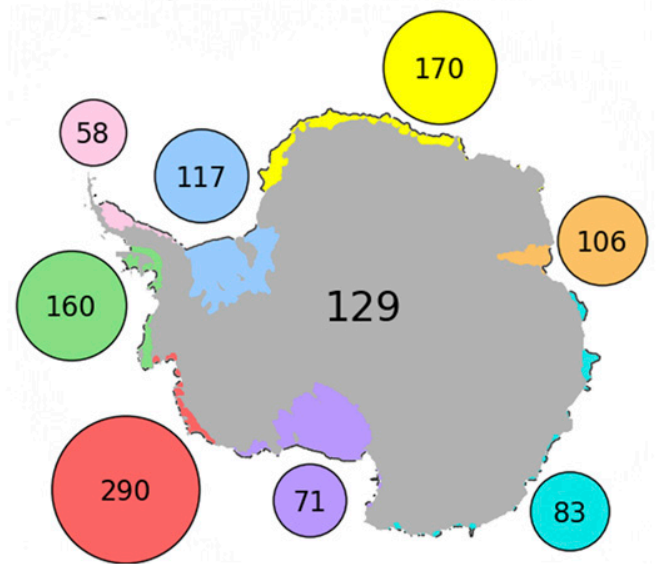

FIG. 3. Percent change in ice shelf basal mass loss for each RCP simulation. Changes are calculated between the 1996-2005 average (10 years preceding RCPs) and 2091-2100 average (last 10 years of each RCP). The results are split into eight sectors of Antarctica, color-coded as follows: Filchner-Ronne Ice Shelf (blue), eastern Weddell region (yellow), Amery Ice Shelf (orange), Australian sector (teal), Ross Sea (purple), Amundsen Sea (red), Bellingshausen Sea (green), and Larsen Ice Shelves (pink). The area of each colored circle is proportional to the value written inside it, which is the percent change in basal mass loss for that sector. The number written in the center of the continent is the percent change in ice shelf basal mass loss over all of Antarctica.

with increases from $16 \%$ to $71 \%$. Changes here are smaller due to strong convection in the Ross Polynya, which erodes the heat content of any warming onshore flow (see section $4 \mathrm{c}$ ).

To assess the significance of the changes shown in Fig. 3, we have also calculated linear trends over the RCP simulations (2006-2100). These trends are significant at the 95\% level for all sectors and all RCP scenarios, with the exception of the Larsen sector for which the trend is not significant during RCP4.5 MMM and RCP4.5 ACCESS. In the control simulation, the only significant trend in basal mass loss is for the Bellingshausen Sea sector, where melt rates increase at approximately one-fifth of the rate seen in the least dramatic RCP simulation (RCP4.5 MMM).

\section{b. Water masses in ice shelf cavities}

Changes in ice shelf basal mass loss can be better understood by examining the evolution of different water masses in ice shelf cavities during the twenty-first century. Figure 4 defines six different water masses based on discrete temperature and salinity boundaries. 


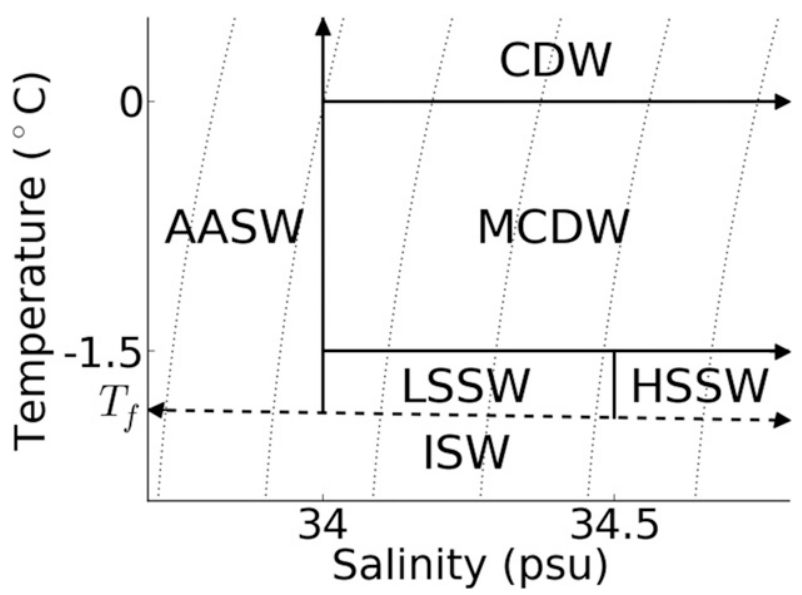

FIG. 4. Schematic showing discrete potential temperature and salinity boundaries used to categorize water masses in ice shelf cavities in Fig. 5. The dashed line $T_{f}$ is the surface freezing point. The dotted curves show potential density contours.

Ice Shelf Water (ISW), below the surface freezing temperature, is the product of melting at the ice shelf base. Antarctic Surface Water (AASW) is relatively fresh and is warmed by the sun in the absence of sea ice. Low Salinity Shelf Water (LSSW) and High Salinity Shelf Water (HSSW) are the products of sea ice formation, with temperatures near the surface freezing point; HSSW is more affected by brine rejection, and thus has higher salinity. Circumpolar Deep Water $(\mathrm{CDW})$, which upwells in the offshore Southern Ocean, is the warmest water mass in ice shelf cavities. As it crosses the continental shelf, it can be modified to varying degrees by mixing with colder water masses, forming Modified Circumpolar Deep Water (MCDW).

Note that in Fig. 4, the only threshold with physical significance is the surface freezing point. Other boundaries are somewhat arbitrary, such as the threshold salinity differentiating LSSW from HSSW, or the temperature range of MCDW. Here we use the same definitions as Naughten et al. (2018), with the addition of CDW as a separate water mass from MCDW. The salinity thresholds are also the same as in Galton-Fenzi (2009).

For each water mass in ice shelf cavities, we calculated its heat content relative to the in situ freezing point, hereafter abbreviated as $\mathrm{HCf}$ :

$$
\mathrm{HCf}=\int\left(T-T_{i f}\right) \rho c_{p w} d V,
$$

where $T$ is potential temperature $\left({ }^{\circ} \mathrm{C}\right), T_{i f}$ is the in situ freezing point $\left({ }^{\circ} \mathrm{C}\right), \rho$ is the potential density $\left(\mathrm{kg} \mathrm{m}^{-3}\right)$, $c_{p w}=4180 \mathrm{~J} \mathrm{~K}^{-1} \mathrm{~kg}^{-1}$ is the specific heat of seawater, and $d V$ is the volume $\left(\mathrm{m}^{3}\right)$ of the given cell (a triangular prism). The integral is performed over all cells in ice shelf cavities in the given region (e.g., the Ross Sea), whose temperature and salinity values satisfy the definition of the given water mass. The in situ freezing point is calculated as follows:

$$
T_{i f}=-0.0575 S+0.0901-7.61 \times 10^{-4} z,
$$

where $S$ is salinity (psu) and $z$ is depth (m; positive). In Eqs. (1) and (2), $T, \rho, S$, and $z$ are averaged over the six vertices of the given cell.

Note that HCf is influenced by the volume of the given water mass as well as its temperature and its position in the water column (which affects the in situ freezing point). HCf represents the amount of energy (in joules) available to melt ice at the given depth, but changes in total $\mathrm{HCf}$ are not equivalent to changes in basal mass loss, because the latter is also influenced by the flushing rate and by ocean velocities at the ice-ocean interface. Note that even ISW generally has a positive $\mathrm{HCf}$, since its temperature typically lies between the surface and in situ freezing points.

Time series of HCf for each water mass in ice shelf cavities, for the eight sectors defined in Fig. 3 as well as the total for all ice shelves, are shown in Fig. 5 for the RCP8.5 MMM simulation. The time series have been scaled as percentages of the initial (1992-2005 mean) total HCf of all water masses in the given region.

Beneath the Filchner-Ronne Ice Shelf, HSSW is replaced by fresher LSSW during the twenty-first century, due to weaker sea ice formation. ISW also declines, which could indicate a shorter residence time with faster flushing of the cavities and/or a warmer source water mass from which the heat is not fully extracted, so that the volume of water cooled below the surface freezing point is reduced. All three water masses exhibit slight warming (not shown), but total HCf in the cavity only increases by $20 \%$ (2091-2100 mean), which is relatively low compared to other cavities. The changes in HCf of individual water masses are therefore dominated by changes in proportional volume rather than temperature. The Ross Sea exhibits similar behavior, with total HCf increasing by only $6 \%$, which indicates an even greater dominance of volume over temperature.

The Amery Ice Shelf cavity is initially dominated by LSSW, but during the first half of the twenty-first century this is replaced by relatively cool MCDW just above the $-1.5^{\circ} \mathrm{C}$ threshold. During the second half of the twenty-first century, this MCDW warms so that its $\mathrm{HCf}$ continues to rise; by 2091-2100, total HCf in the cavity has increased by $56 \%$. An increasing presence of fresh AASW is also evident. The Australian sector is initially more dominated by MCDW but exhibits a loss of LSSW similar to the Amery. Enhanced HCf from AASW is more evident in this region, due to increases in both volume and temperature. 


\section{Heat content (above freezing point) of water masses in ice shelf cavities: RCP 8.5 MMM}

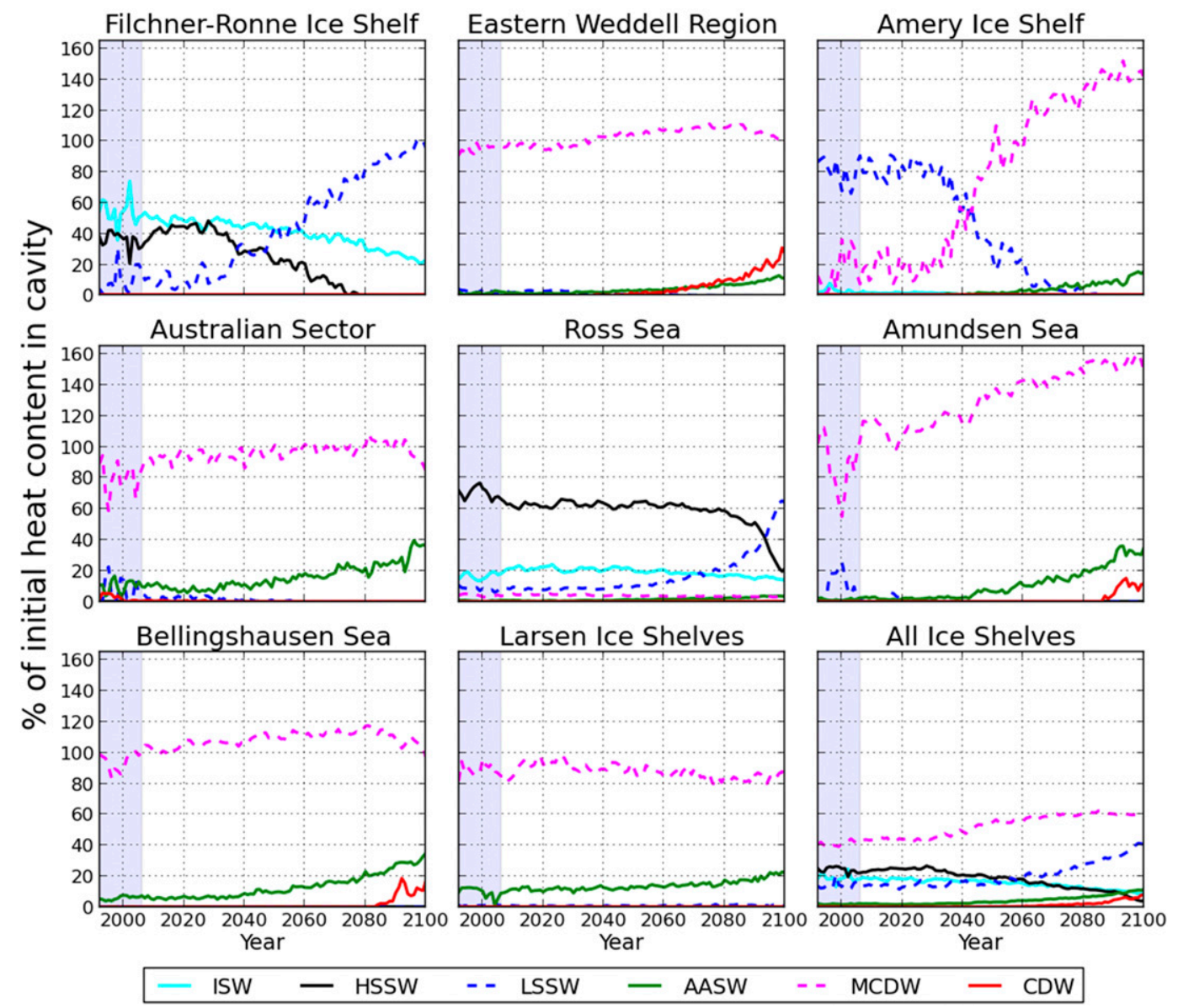

FIG. 5. Annually averaged time series of the heat content of different water masses (categorized in Fig. 4) in ice shelf cavities during the RCP8.5 MMM simulation. Heat content is calculated relative to the in situ freezing point, and therefore represents the amount of energy in joules available to melt ice at the given depth. Here it is scaled as a percentage of the initial (1992-2005 mean) heat content of all water masses in the given region (again relative to the in situ freezing point). Results are shown for the eight sectors defined in Fig. 3, as well as the total for all ice shelves. The years 1992-2005, preceding the RCP period, are shaded in light blue. Versions of this figure for the other three RCP simulations are available in the online supplemental material.

In both the eastern Weddell region and the Bellingshausen Sea, HCf from MCDW slightly increases during most of the twenty-first century. The volume of MCDW is actually stable or declining during this time, as some of it is replaced by fresher AASW, but its temperature is increasing. During the last 20 years of the simulation, this warming reaches the point where the HCf of MCDW declines due to replacement by CDW.

The most pronounced changes are seen in the Amundsen Sea, where total HCf doubles during the twenty-first century. The cavities in this region are initially dominated by LSSW and cool MCDW, but substantial warming of MCDW (by approximately $1^{\circ} \mathrm{C}$ ) causes its $\mathrm{HCf}$ to increase throughout the twenty-first century, with an eventual contribution from CDW. This occurs despite a decrease in the volume of MCDW, due to replacement by fresher AASW (related to the increasing stratification described in section $4 \mathrm{~d}$ ). That is, more heat is contained in a smaller volume of MCDW, as it is less modified.

The Larsen Ice Shelves show the least pronounced changes in HCf, with a slight shift from MCDW to AASW due to freshening. There is very little contribution from warming, as total HCf increases by only $6 \%$.

\section{c. Mechanisms of warming in ice shelf cavities}

Enhanced ice shelf basal melting is primarily the result of ocean warming in ice shelf cavities, but this 
warming can occur through several different processes. Figure 6 highlights these processes for a single scenario (RCP8.5 MMM), comparing the period 2091-2100 to 1996-2005 as before. Figure 6a plots the maximum warming attained at any depth for each horizontal point in ice shelf cavities (note the nonlinear color scale), while Fig. $6 \mathrm{~b}$ plots the fractional depth below the ice shelf base of this maximum warming ( 0 is the ice shelf base, 1 is the seafloor). Figure $6 \mathrm{c}$ plots a seasonality metric based on monthly climatologies (defined in the figure caption), where 0 indicates no seasonality in the warming signal.

Two main mechanisms of warming can be identified: 1) surface-dominated and 2) bottom-dominated warming [corresponding to mode 3 and mode 2 ice shelf melting respectively, as in Jacobs et al. (1992)]. Surfacedominated warming is characterized by fractional depths near 0 and high seasonality. Warming in this case is driven by a decline in summer sea ice cover, which exposes a greater fraction of the ocean surface to incoming solar radiation and changes in incoming longwave radiation. This surface water warms and may subduct beneath ice shelves. Regions affected by surface-dominated warming include the Filchner, Larsen, and Wilkins Ice Shelves, the eastern half of the eastern Weddell region, the Australian sector, and the Ross Ice Shelf front.

Conversely, bottom-dominated warming has fractional depths near 1 and low seasonality. This type of warming indicates an increased presence of CDW or MCDW, whose temperature is unaffected by the seasonal cycle. Bottom-dominated warming tends to have a larger magnitude than surface-dominated warming in our simulations, as seen by larger values in Fig. 6a. The Amundsen Sea is the most affected region and is explored in more detail in the next section. Also affected are the Abbot and Amery Ice Shelves, the western half of the eastern Weddell region, and the Ronne Ice Shelf.

Unlike other twenty-first-century projections with FESOM, which were forced with output from the HadCM3 model (Timmermann and Hellmer 2013; Timmermann and Goeller 2017), our simulations do not show a redirection of the Antarctic Coastal Current beneath the Filchner-Ronne Ice Shelf. Comparing FESOM results between experiments forced with HadCM3 and ECHAM5 output, Timmermann and Hellmer (2013) showed that the occurrence of this transition is highly sensitive to the atmospheric forcing. Our simulations show a combination of processes driving melting beneath FRIS. The largest increases in melt occur immediately east of Berkner Island, due to inflow of warmer AASW. The Ronne Ice Shelf cavity is also slightly affected by bottom-dominated warming, due to
RCP 8.5 MMM, 2091-2100 minus 1996-2005

a) Maximum warming over depth $\left({ }^{\circ} \mathrm{C}\right)$

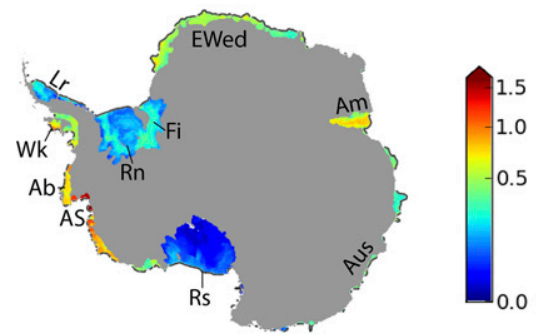

b) Fractional depth below ice shelf base of maximum warming

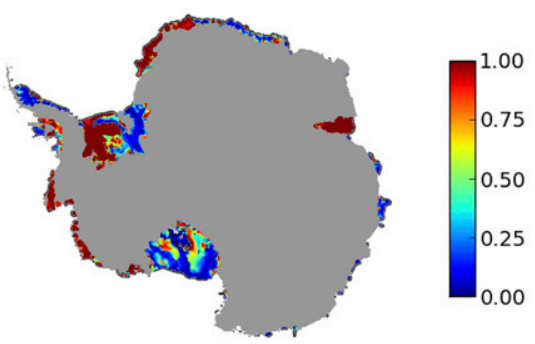

c) Seasonality metric

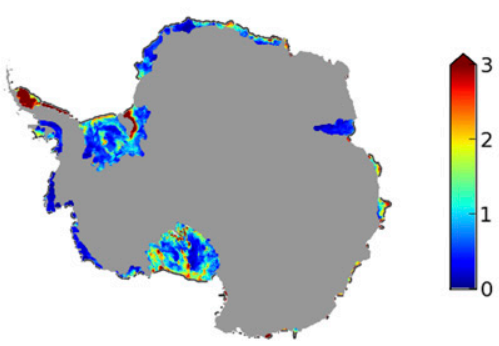

FIG. 6. Details of warming in ice shelf cavities during the RCP8.5 MMM simulation. (a) Maximum ocean warming attained at any depth, between the 1996-2005 average and the 2091-2100 average. Nodes with cooling throughout the entire water column (mainly near the back of the Ross Ice Shelf) are masked in white in all three panels. Note the nonlinear color scale. (b) Fractional depth below the ice shelf base of this maximum warming, where 0 is the ice shelf base and 1 is the seafloor. (c) Seasonality of this warming, calculated using monthly climatologies for 1996-2005 and 2091-2100, at the depth shown in (b) for each horizontal node. The seasonality metric is defined as the difference in warming between the months with maximum and minimum warming at the given node, divided by the annual warming shown in (a). A value of 0 thus indicates no seasonality, while a value of 3 indicates a seasonal cycle in the warming signal which is 3 times the annual mean warming. $\mathrm{Rn}=$ Ronne Ice Shelf; $\mathrm{Fi}=$ Filchner Ice Shelf; $\mathrm{EWed}=$ eastern Weddell region; $\mathrm{Am}=$ Amery Ice Shelf; Aus = Australian sector; Rs = Ross Ice Shelf; AS $=$ Amundsen Sea; Ab = Abbot Ice Shelf; Wk = Wilkins Ice Shelf; $\mathrm{Lr}=$ Larsen Ice Shelves. Versions of this figure for the other three RCP simulations are available in the supplemental material. 
Amundsen Sea

1996-2005 RCP 4.5 MMM RCP 4.5 ACCESS RCP 8.5 MMM RCP 8.5 ACCESS CONTROL a) Bottom water temperature $\left({ }^{\circ} \mathrm{C}\right)$
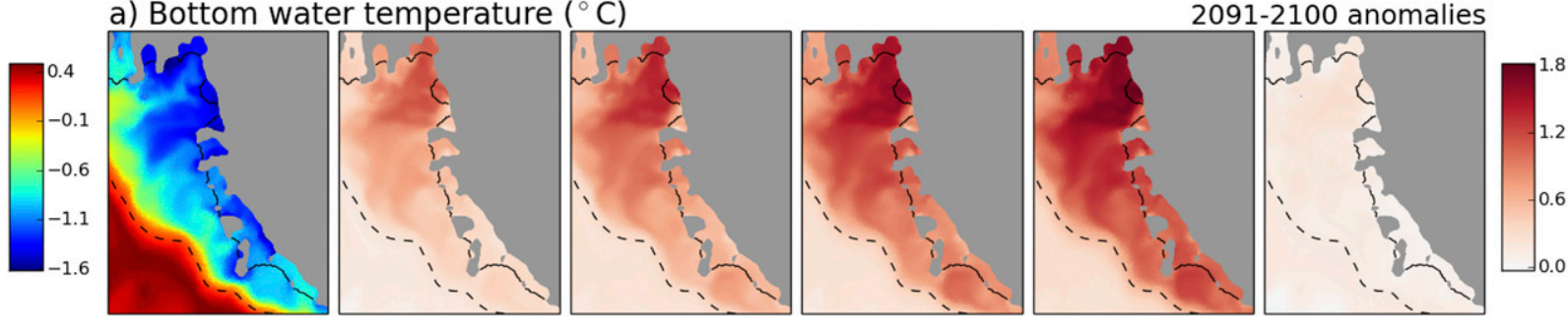

b) Ice shelf melt rate $(\mathrm{m} / \mathrm{y})$
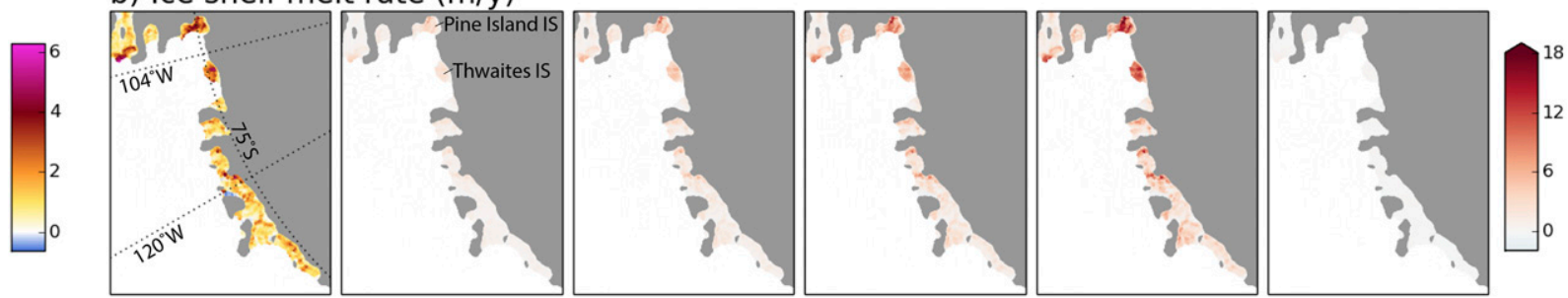

c) Bottom water salinity (psu)
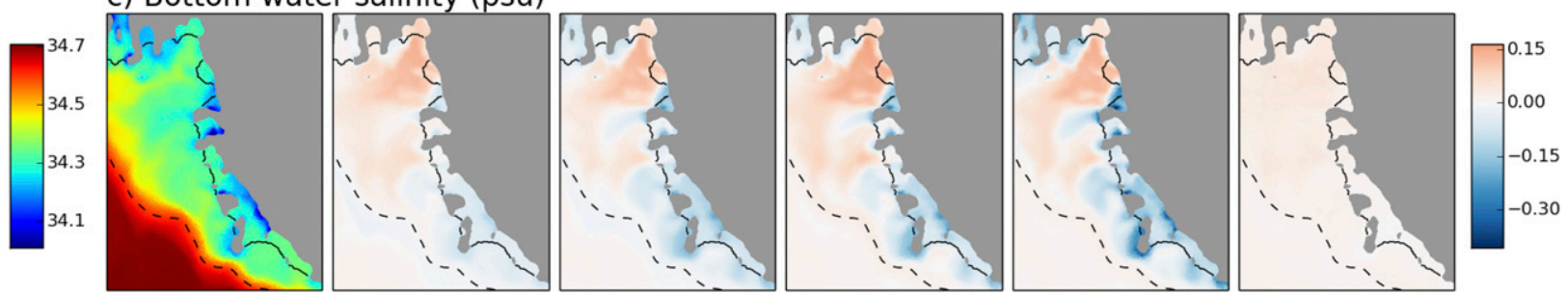

FIG. 7. Conditions in the Amundsen Sea region, showing absolute variables for (left) the 1996-2005 average and the anomalies with respect to this baseline for the 2091-2100 average in (middle four columns) each RCP simulation and (right) the CONTROL experiment. (a) Bottom water temperature $\left({ }^{\circ} \mathrm{C}\right)$. The dashed black line shows the $1500-\mathrm{m}$ isobath, which approximates the continental shelf break. (b) Ice shelf melt rate $\left(\mathrm{m} \mathrm{yr}^{-1}\right)$. The anomaly color scale is capped at $18 \mathrm{~m} \mathrm{yr}^{-1}$ for visibility; the true maximum anomaly is $24.8 \mathrm{~m}$ yr ${ }^{-1}$. IS $=$ ice shelf. (c) Bottom water salinity (psu).

an eastward shift in sea ice formation near the ice shelf front (see section $4 \mathrm{~g}$ ). Reduced convection in the Ronne Depression allows a warmer bottom layer to develop, consisting of warm LSSW or highly modified MCDW (maximum temperature of $-1.4^{\circ} \mathrm{C}$ in RCP8.5 ACCESS), which subsequently flows into the Ronne Ice Shelf cavity.

\section{d. CDW in the Amundsen Sea}

A region of particular interest in our simulations is the Amundsen Sea sector, which experiences the largest increase in ice shelf basal mass loss of any Antarctic region, due to strong bottom-dominated warming. Prior to the RCPs (1996-2005), our FESOM configuration exhibits a cold bias in the Amundsen Sea, with bottom water temperatures around $-1^{\circ} \mathrm{C}$ on the continental shelf (Fig. 7a). By comparison, observations in this region suggest temperatures around $1{ }^{\circ} \mathrm{C}$ (Jacobs et al. 2011; Jenkins et al. 2010; Dutrieux et al. 2014). As a result, our FESOM configuration underestimates ice shelf melt rates in the Amundsen Sea compared to observation-based estimates (Naughten et al. 2018). This model bias is largely due to unrealistically strong sea ice formation in the Amundsen Sea, which fills the continental shelf with cold LSSW and erodes most of the warm signal from MCDW in the bottom layer. Other possible contributors to this cold bias are a spuriously large mixing along sigma coordinate lines (Nakayama et al. 2014), as well as unresolved mesoscale eddies that would otherwise transport heat across the shelf break (Stewart and Thompson 2015).

By the end of all four RCP simulations, this cold bias has been largely overtaken by warming. Significant warm anomalies are apparent in bottom water temperature on the Amundsen Sea continental shelf, particularly in front of the Pine Island and Thwaites Ice Shelves (Fig. 7a). The RCP8.5 ACCESS simulation experiences the strongest warming, of up to $1.8^{\circ} \mathrm{C}$. Ice shelf melt rates 


\section{RCP 8.5 ACCESS, $104^{\circ} \mathrm{W}$ (Amundsen Sea), September}

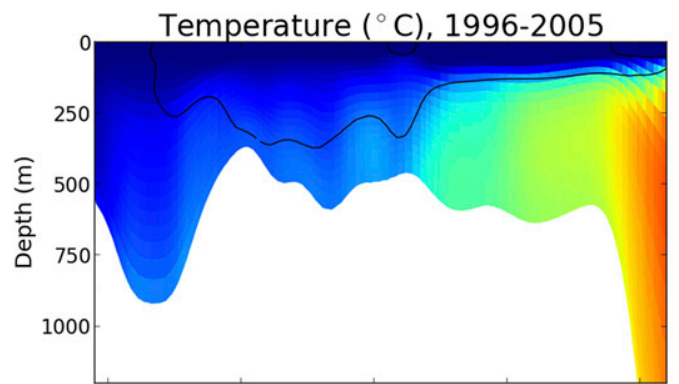

Salinity (psu), 1996-2005

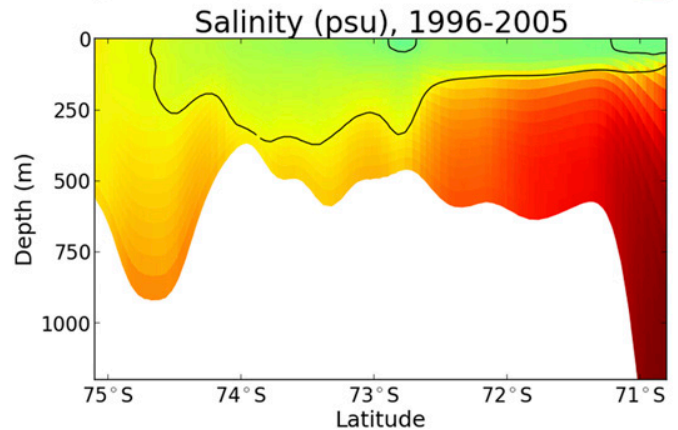

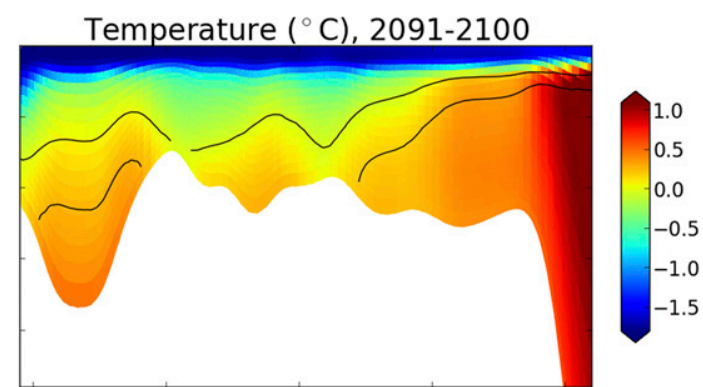

Salinity (psu), 2091-2100

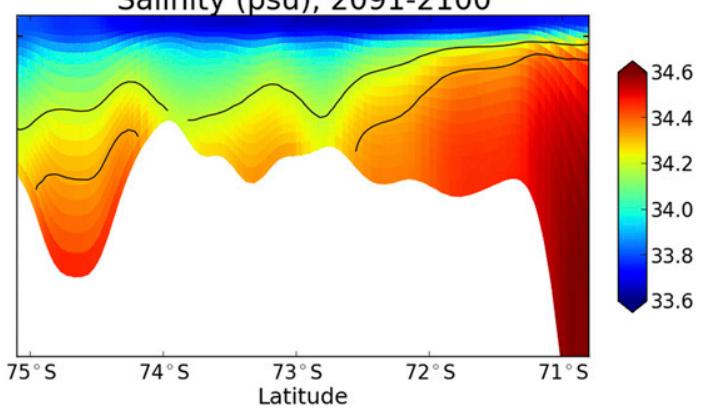

FIG. 8. Meridional slices of (top) temperature $\left({ }^{\circ} \mathrm{C}\right.$ ) and (bottom) salinity (psu) interpolated to $104^{\circ} \mathrm{W}$ through the Amundsen Sea (line of longitude marked in Fig. 7b). Results are shown for the September monthly average, in (left) the 1996-2005 climatology and (right) the 2091-2100 climatology, for the RCP8.5 ACCESS simulation. The black lines show potential density contours for 1027.45 and $1027.55 \mathrm{~kg} \mathrm{~m}^{-3}$.

increase (Fig. 7b), with total basal mass loss from the Pine Island and Thwaites Ice Shelves approximately quadrupling during the RCP8.5 ACCESS simulation. The warm anomalies coincide with salinification of up to $0.15 \mathrm{psu}$ in the bottom layer (Fig. 7c). This combination of increased temperature and salinity indicates that the warming is due to an enhanced presence of CDW on the continental shelf.

This increase in CDW is driven by stratification, as shown in Fig. 8 with meridional slices of temperature and salinity through $104^{\circ} \mathrm{W}$, during September when convection is strongest. Prior to the RCPs (1996-2005, left column), temperature and salinity on the continental shelf are relatively uniform with depth. Sea ice formation has destabilized the entire water column, so the warmth of the bottom layer is lost to the atmosphere due to deep convection. However, by the end of RCP8.5 ACCESS (2091-2100; right column), the water column has stratified. The cold surface water is now too fresh to form a deep mixed layer, so the underlying CDW $\left(>0^{\circ} \mathrm{C}\right)$ is preserved. Analysis of the surface freshwater budget reveals the primary cause of this freshening to be reduced sea ice formation.

In reality, the present-day Amundsen Sea may not be capable of experiencing much further warming, since it is already inundated with unmodified CDW. The warming seen in our simulations should therefore be interpreted as the reversal of a model bias, rather than as a reliable projection for the Amundsen Sea region. However, the mechanism of warming-reduced sea ice formation stratifying the water column and permitting greater onshore transport of CDW and MCDW-is still valid and could apply to many regions of Antarctica. In our simulations, this mechanism is visible to a lesser extent in the Bellingshausen Sea, the Amery Ice Shelf cavity, and the western half of the eastern Weddell region (Brunt, Riiser-Larsen, Ekstrom, Jelbart, and Fimbul Ice Shelves). It is also useful to note that the model's Amundsen Sea cold bias is sensitive to atmospheric forcing (as also found by Nakayama et al. (2014) for a different configuration of FESOM), and is not necessarily an intrinsic feature of this model configuration.

Transport of CDW onto the continental shelf can also be affected by changes in wind stress, which affect Ekman upwelling at the shelf break (Schmidtko et al. 2014). In particular, strengthening and poleward shifting of the Southern Hemisphere westerly winds has been suggested as a mechanism to cause warming on the continental shelf of West Antarctica (Spence et al. 2014, 2017). Among our experiments, the RCP8.5 MMM scenario experiences the most pronounced changes in winds. Here the bias-corrected atmospheric forcing shows a similar strengthening, but a smaller southward shift, of the Southern Hemisphere westerlies compared 
Water masses south of $65^{\circ} \mathrm{S}$

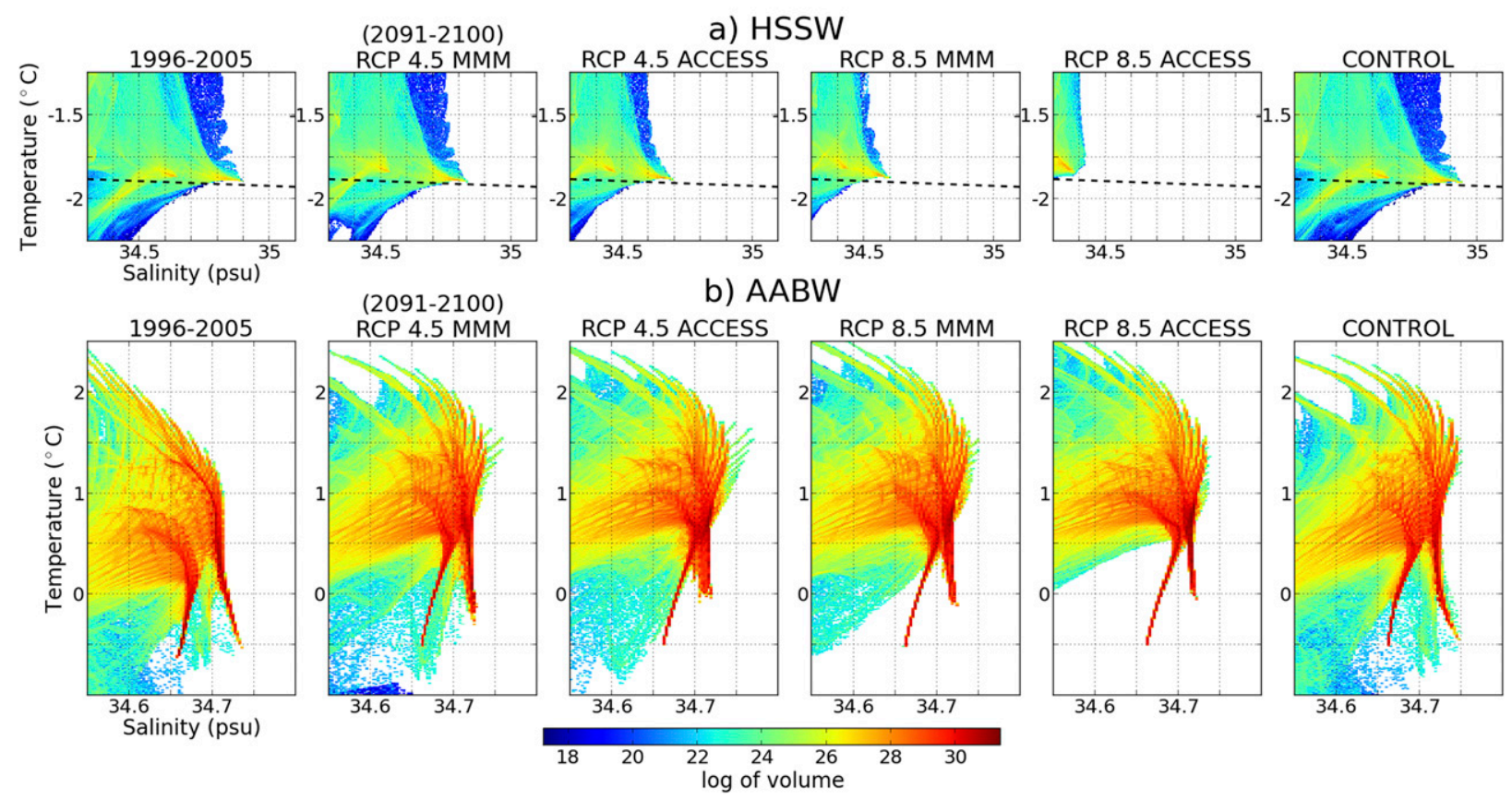

FIG. 9. Temperature-salinity distribution of water masses south of $65^{\circ} \mathrm{S}$, averaged over (left) the years $1996-2005$ as well as (middle four columns) 2091-2100 for each RCP experiment and (right) the CONTROL experiment. Each triangular prism south of $65^{\circ} \mathrm{S}$ in the FESOM mesh is sorted into $1000 \times 1000$ temperature and salinity bins. The color scale shows the log of the volume $\left(\mathrm{m}^{3}\right)$ of each bin, and the dashed lines in (a) show the surface freezing point. Results are shown zoomed into two different regions of the distribution: (a) HSSW and (b) AABW.

to the idealized wind changes applied by Spence et al. (2014). To quantify the effects of changing wind stress on ice shelf melting in our simulations, we performed an additional experiment identical to RCP8.5 MMM, but with no changes in the winds. That is, the wind fields were held fixed at the 1992-2005 monthly climatology, with submonthly variability superimposed as before, but zero monthly anomalies throughout the RCP. By 20912100, ice shelf basal mass loss from the Amundsen Sea sector was $2.8 \%$ lower than in the original RCP8.5 MMM simulation, and basal mass loss from the entire continent was $0.6 \%$ higher. Therefore, the changes in ice shelf melting we simulate during the twenty-first century do not appear to be primarily caused by changes in wind stress. This is in agreement with the results of DonatMagnin et al. (2017), who found that including ice shelf thermodynamics in a regional model of the Amundsen Sea reduced the sensitivity of continental shelf temperatures to changes in the winds.

\section{e. Changes in HSSW and $A A B W$}

Temperature-salinity distributions of water masses south of $65^{\circ} \mathrm{S}$ are shown in Fig. 9, averaged over the period 1996-2005 (left column) as well as 2091-2100 for each RCP experiment and the control experiment.
Figure 9a zooms into the HSSW part of the distribution, which freshens in all four RCP scenarios. The magnitude of this freshening ranges from approximately $0.05 \mathrm{psu}$ in RCP4.5 MMM to almost 0.5 psu in RCP8.5 ACCESS. In fact, by the end of RCP8.5 ACCESS no water at all would be classified as HSSW using the definition in Fig. 4 (salinity $\geq 34.5 \mathrm{psu}$ ), neglecting the seasonal cycle. By contrast, HSSW in the control simulation becomes slightly saltier, by approximately 0.05 psu.

HSSW is the product of strong sea ice formation and the resultant brine rejection, and its decline in the RCP simulations is driven by warmer winter air temperatures causing weaker sea ice formation (section $4 \mathrm{~g}$ ). The resulting water masses shift toward LSSW properties, which are less affected by brine rejection, and consequently fresher and less dense. Export of cold water down the continental slope, which feeds AABW, is therefore inhibited, and AABW would be expected to warm as a result.

Figure $9 \mathrm{~b}$ zooms into the AABW part of the distribution, which is characterized by a double-forked feature. The fresher fork is Weddell Sea Bottom Water (WSBW), and the saltier fork is Ross Sea Bottom Water (RSBW) (Naughten et al. 2018). Both forks display warming during the RCP simulations, as expected. This 
warming is more pronounced for RSBW, with changes of approximately $0.5^{\circ} \mathrm{C}$ in the RCP8.5 ACCESS simulation.

In the CONTROL experiment, no significant drift is seen for the cold WSBW and RSBW forks, but the warmer varieties of $\mathrm{AABW}$ and $\mathrm{CDW}\left(>0^{\circ} \mathrm{C}\right)$ become warmer as well as saltier. This drift is affected by deep ocean processes operating on centennial to millennial time scales, which are not expected to stabilize during our relatively short spinup of 28 years.

\section{f. Changes in large-scale circulation}

Our simulations show a weakening of the ACC in response to twenty-first-century climate change. Over the period 1996-2005, the mean transport through Drake Passage $\left(67^{\circ} \mathrm{W}\right)$ is $144 \mathrm{~Sv}\left(1 \mathrm{~Sv} \equiv 10^{6} \mathrm{~m}^{3} \mathrm{~s}^{-1}\right)$. By $2091-2100$, this has weakened by $13 \%, 16 \%, 13 \%$, and $17 \%$ in RCP4.5 MMM, RCP4.5 ACCESS, RCP8.5 MMM, and RCP8.5 ACCESS, respectively. The absolute reductions in transport are 19, 23, 19, and $24 \mathrm{~Sv}$, respectively. The control simulation also shows a weakening of $8 \%$ ( $11 \mathrm{~Sv}$ ), which may be due to diapycnal mixing in the deep ocean (Naughten et al. 2018). The more pronounced ACC weakening seen in the RCP simulations indicates that forced changes, as well as drift, are underway. These changes cannot be attributed to weakening of the Southern Hemisphere westerly winds, because in fact these winds strengthen slightly in all four forcing scenarios. Rather, near-surface freshening around the Antarctic continent reduces the meridional density gradient across the Southern Ocean, causing zonal transport to weaken. The same phenomenon was apparent in the climate change simulations of Hattermann and Levermann (2010), although after 150 years it was overwhelmed by the effects of deep ocean warming, which ultimately drove a strengthening of the ACC.

While freshening around Antarctica reduces the density gradient across the Southern Ocean, it strengthens the density gradient across the continental slope, which in our simulations causes the Antarctic Coastal Current to strengthen. We estimate the speed of this current in $1^{\circ}$ longitude bins by selecting the maximum time-averaged surface speed of all nodes within the given bin that are south of $64^{\circ} \mathrm{S}$ with bathymetry shallower than $2500 \mathrm{~m}$. For the 1996-2005 average, the mean Antarctic Coastal Current speed across all longitude bins is $0.13 \mathrm{~m} \mathrm{~s}^{-1}$. During each RCP scenario, the mean percentage increase in speed across all longitude bins (2091-2100 vs $1996-2005)$ is $11 \%, 27 \%, 29 \%$, and $52 \%$ for RCP 4.5 MMM, RCP4.5 ACCESS, RCP8.5 MMM, and RCP8.5 ACCESS, respectively. The largest changes occur between $80^{\circ} \mathrm{W}$ and $180^{\circ}$, which contains the Bellingshausen, Amundsen, and eastern Ross Seas. Since the Amundsen and Bellingshausen Seas exhibit the greatest increases in ice shelf basal melting (section 4a), it is logical that the resulting meltwater would strengthen the coastal current locally as well as immediately downstream in the eastern Ross Sea. During the same period in the CONTROL experiment, residual drift causes the Antarctic Coastal Current to slightly slow, by an average of $3 \%$ over all longitude bins.

Because of the counteracting effects of the weakening ACC and strengthening coastal current, our simulations show no consistent trends in subpolar gyre strength for either the Ross or Weddell Sea. The Ross Gyre weakens in RCP4.5 MMM but strengthens in RCP8.5 MMM (both significant at the $95 \%$ level), with no significant trends in the simulations forced with ACCESS. Conversely, the Weddell Gyre strengthens in RCP4.5 ACCESS and weakens in RCP8.5 ACCESS, with no significant trends in the simulations forced with the multimodel mean. Both gyres weaken during the CONTROL experiment, due to the weakening ACC but stable coastal current.

\section{g. Changes in sea ice}

Our configuration of FESOM underestimates the present-day Antarctic sea ice minimum by approximately a factor of 2 (Naughten et al.2018), which is a common bias among coupled ocean-sea ice models (Downes et al. 2015). In some years of the control simulation, February Antarctic sea ice extent is near zero. With very little summer sea ice left to lose, analyzing changes in the Antarctic sea ice minimum during the RCP experiments would be of limited use.

Changes in the sea ice maximum are more robust, as our FESOM configuration more or less reproduces observed September sea ice extent (Naughten et al. 2018). Figure 10 plots September sea ice concentration averaged over 1996-2005, as well as the anomalies during 2091-2100 for each RCP simulation and the control experiment. The northern edge of the sea ice pack retreats in all four RCP simulations, with the greatest declines in the Amundsen and Bellingshausen Seas (as observed in recent decades; Meier et al. 2013) and off the coast of East Antarctica.

These anomalies represent a decline in September total Antarctic sea ice extent (calculated as the area of mesh elements with sea ice concentration exceeding 0.15 ) of $18 \%, 18 \%, 30 \%$, and $35 \%$ for RCP $4.5 \mathrm{MMM}$, RCP4.5 ACCESS, RCP8.5 MMM, and RCP8.5 ACCESS, respectively. These declines are similar to the sea ice projections simulated directly by the CMIP5 multimodel mean and ACCESS 1.0 (A. Purich 2017, personal communication) which indicates that ice shelf meltwater has minimal effect on sea ice changes in our simulations. 
September sea ice concentration
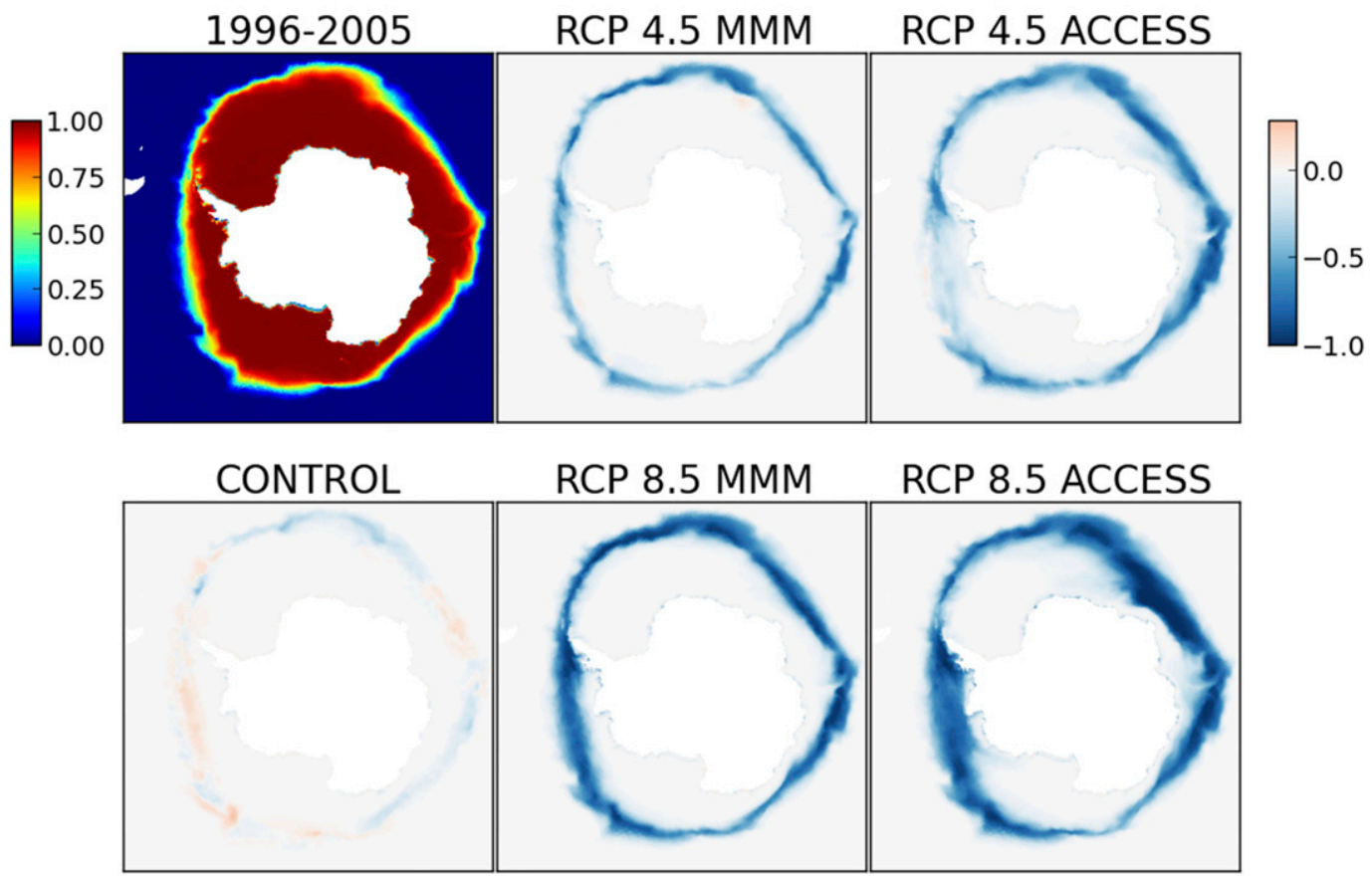

anomalies (2091-2100 minus 1996-2005)

FIG. 10. Sea ice concentration (fraction) averaged over September, the month of maximum sea ice extent. Absolute concentration is shown for the 1996-2005 average, and anomalies for 2091-2100 with respect to 19962005 are shown for the four RCP simulations and the CONTROL simulation.

This is in contrast to the results of Merino et al. (2018), who found that prescribing ice shelf and iceberg meltwater led to nonnegligible changes in simulated sea ice extent.

Changes in sea ice formation and melt during the RCP8.5 MMM simulation are shown in Fig. 11, with seasonal averages for the 1996-2005 baseline (Fig. 11a) as well as anomalies for 2091-2100 (Fig. 11b). Positive anomalies indicate more freezing or less melting, depending on the sign of the initial field, and vice versa for negative anomalies. In general, freezing and melting both weaken, indicating a reduction in intensity of the sea ice cycle.

Summer (DJF) is dominated by reduced melting, as there is less sea ice available to melt, except in the southern Weddell and Ross Seas, which experience increased melting of multiyear ice. Similarly, offshore regions show year-round reductions in melting. Warmer temperatures also cause the transition zone between freezing and melting to shift southward, which is particularly visible in spring (SON). The cooler seasons show widespread weakening of sea ice formation on the continental shelf, as noted in previous sections. In the Ross and Weddell Seas some shifts in the regions of strongest sea ice formation are visible, characterized by adjacent positive and negative anomalies. In particular, wintertime (JJA) sea ice formation shifts eastward out of the Ronne Depression, and northward in the Ross Sea.

Across the seasonal cycle, the net effect of these changes is to reduce the transport of freshwater away from the Antarctic coast, with consequent effects on Southern Ocean density gradients as described in section $4 \mathrm{f}$.

\section{Summary and discussion}

In our simulations, ice shelf basal melting increases in every sector of Antarctica and in every twenty-firstcentury forcing scenario. Perhaps the most significant result in our simulations is the effect of reduced sea ice formation on ice shelf basal melting, which confirms and extends the findings of Timmermann and Hellmer (2013). In the simulated present-day climate, sea ice formation drives convection on the continental shelf, which protects ice shelf cavities from warm CDW and 
Net sea ice formation (+) or melt (-), m/y

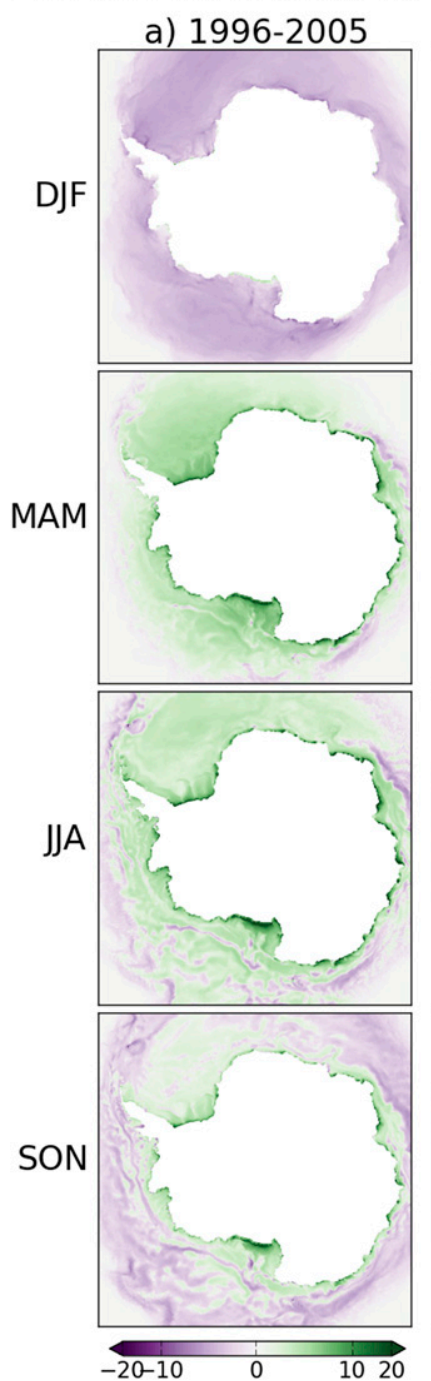

b) RCP $8.5 \mathrm{MMM}$
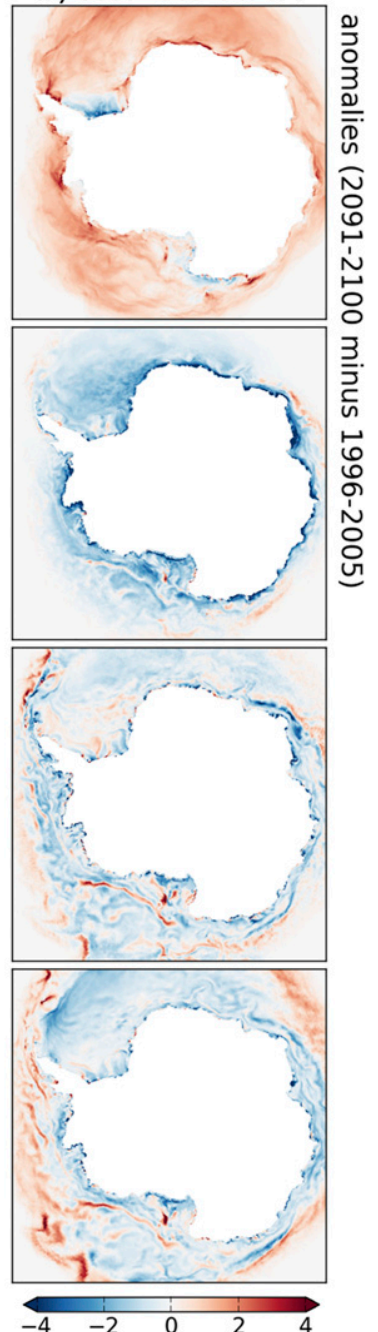

FIG. 11. (a) Net sea ice formation (positive) or melt (negative) $\left(\mathrm{m} \mathrm{yr}^{-1}\right)$ for each season in the 1996-2005 mean. Note the nonlinear color scale. (b) Anomalies for 2091-2100 with respect to 1996-2005 in the RCP8.5 MMM simulation.

MCDW intruding from offshore. During the simulated twenty-first century, warmer winters with less sea ice formation cause increased stratification of the water column. Shallower mixed layers allow a warm bottom layer of CDW or MCDW to develop in many regions, most notably the Amundsen Sea. In the warmest scenario (RCP8.5 ACCESS), ice shelf basal mass loss from the Amundsen Sea quadruples as a result. The simulations of Timmermann and Hellmer (2013) and Timmermann and Goeller (2017) showed a similar mechanism, but mainly affecting the southern Weddell Sea rather than the Amundsen Sea, and aided by a redirected coastal current.

Some ice shelf cavities affected by this bottomdominated warming, such as the eastern Weddell region and the Amery Ice Shelf, also exhibit excessive MCDW in present-day simulations (Naughten et al. 2018), which is possibly due to oversmoothing of the continental slope. Conversely, the Amundsen Sea has unrealistically strong modification of CDW in presentday simulations, as described in section $4 \mathrm{~d}$. These present-day biases may affect the simulated future changes, and our projections should therefore be interpreted with caution.

For other ice shelves, such as the Ross and the Filchner, simulated increases in melting are instead driven by warmer AASW, which subducts beneath the ice shelf front. This process is tied to reductions in sea ice, as an increased area of open water raises sea surface temperatures due to solar heating. The same process was found in the future projections of Timmermann and Goeller (2017) for the FRIS region, although increased melting in these simulations was mainly caused by MCDW. Naughten et al. (2018) also highlighted concerns with oversmoothed ice shelf fronts, particularly the Ross, allowing relatively warm surface waters to enter the cavity too easily. This may mimic the effects of tides, which are absent in FESOM, on water mass exchanges at the ice shelf front. Nonetheless, some amount of increased melting from warming AASW would be expected regardless of geometry.

Trends in simulated water mass proportions in ice shelf cavities reflect the increased presence of CDW, warmer MCDW, and AASW, which can all be attributed to reductions in sea ice formation or extent. We also simulate a reduction in HSSW, which is replaced by fresher LSSW due to weaker sea ice formation in the Ross and Weddell Seas. Freshening of HSSW on the continental shelf is also apparent in temperaturesalinity distributions. The export of HSSW off the continental shelf is inhibited due to its lower density, and as a result the colder varieties of AABW (Ross Sea and Weddell Sea Bottom Water) warm.

We simulate a weakening of the Antarctic Circumpolar Current due to freshening around the Antarctic continent (again caused by weakened sea ice formation), which reduces the meridional density gradient across the Southern Ocean. Across the continental slope, a stronger density gradient causes the Antarctic Coastal Current to increase in speed.

Most of the changes during the twenty-first century are more pronounced in the simulations forced with ACCESS 1.0 as compared to the CMIP5 multimodel mean. This is due to the greater warming over the Southern Ocean simulated by ACCESS 1.0. As expected, changes are also more pronounced in the 
RCP8.5 scenario than the RCP4.5 scenario, with the exception of ACC weakening, which is approximately the same between the two scenarios. We do not simulate any major threshold changes in FESOM's response to twenty-first-century forcing. Rather, the four simulations exhibit largely the same patterns of behavior along a continuum of severity. This may be due to the stand-alone nature of our simulations, as coupling with an atmosphere and/or ice sheet model would allow for other nonlinear positive feedbacks to develop.

This work builds on previous studies with FESOM, where future projections were integrated using the atmospheric output of CMIP3 models without bias correction. Simulations forced with the HadCM3 model (Timmermann and Hellmer 2013; Timmermann and Goeller 2017) revealed a tipping point in the southern Weddell Sea, whereas our results show more gradual changes. FESOM simulations forced with uncorrected output from the CMIP5 model HadGEM2 (Timmermann and Kauker 2014) also show gradual increases in ice shelf melting around Antarctica, with no tipping points. These differences in behavior illustrate the sensitivity of sub-ice shelf processes to atmospheric forcing, and the importance of constraining climate projections in order to better predict the response of the ice shelves and ice sheet. At the time of writing, the only other published future projections of ice shelf melting forced with CMIP output are from the BRIOS model (Hellmer et al. 2012, 2017). These simulations use the same HadCM3 forcing as the FESOM CMIP3 simulations mentioned above, and display similar behavior.

While our bias-correction method was successful in this instance, it should be applied with caution by others in the future. In particular, CMIP5 models should be chosen whose historical simulations are as close to atmospheric reanalyses as possible, so that the biascorrection term is small. This approach minimizes the risk of applying state-dependent future changes which depend on underlying biases in the CMIP5 models and also avoids potential artifacts in the corrected forcing such as unrealistic wind fields. As noted in section 2, biases in ERA-Interim over the Southern Ocean may also influence our constructed forcing fields. However, in most cases the biases of atmospheric reanalyses such as ERA-Interim are likely to be small compared to those of global climate models unconstrained by observations. Furthermore, our initial conditions for the deep ocean are not yet equilibrated to the forcing period 1992-2005, which is itself a perturbation from the preindustrial climate. Therefore, some forced trends may be influencing our CONTROL simulation.

Finally, our experiments assume that ice shelf geometry will not change during the twenty-first century. This assumption is clearly problematic, as ice shelves are already responding to climate change with thinning (Paolo et al. 2015) and collapse (Rott et al. 1996; Rack and Rott 2004; Hogg and Gudmundsson 2017). Furthermore, the coupled ice sheet-ocean simulations of Timmermann and Goeller (2017) indicate that an evolving ice shelf draft tends to enhance, not damp, increases in basal melt rates during warming scenarios. Donat-Magnin et al. (2017) also found that prescribed grounding line retreat in the Amundsen Sea region led to increased melt rates, due to stronger buoyancy-driven circulation within the cavities.

Our projections of melt rates have particularly troubling implications for the marine sectors of the ice sheet that are grounded below sea level, including the Amundsen Basin as well as the Wilkes and Aurora Basins (both within the Australian sector in our analysis and exhibiting similar behavior). Standalone ice sheet modeling has demonstrated the vulnerability of these marine basins to ocean warming (Feldmann and Levermann 2015; Mengel and Levermann 2014; Sun et al. 2016), illustrating the need for fully coupled ice sheet-ocean simulations to provide more reliable future projections. The potential collapse of marine sectors of the Antarctic Ice Sheet, and corresponding global sea level rise, is one of the most profound yet poorly understood impacts of climate change, and further model development is essential to better predict this behavior in the twenty-first century and beyond.

Acknowledgments. We thank Marta Kasper, Yoshihiro Nakayama, and Lukrecia Stulic for assistance installing and configuring FESOM and Dmitry Sein for assistance generating the unstructured mesh. We are also grateful to Ariaan Purich for helpful discussions regarding CMIP5 sea ice projections. This research was supported by an Australian Government scholarship under the Australian Postgraduate Award and Research Training Program schemes, a UNSW Research Excellence Award, and UNSW Science Silver Star and Gold Star Awards. Support was also provided by the Australian Research Council's Centre of Excellence for Climate System Science and the Australian Government's Cooperative Research Centre Programme through the Antarctic Climate and Ecosystems Cooperative Research Centre. Computational resources were provided by the NCI National Facility at the Australian National University, through awards under the Merit Allocation Scheme, the Intersect allocation scheme, and the UNSW HPC at NCI Scheme. Ben Galton-Fenzi is supported under the Australian Research Council's Special Research Initiative for the Antarctic Gateway Partnership SRI40300001, which also contributes to the World Climate Research 
Programme (WCRP) Climate and Cryosphere (CliC) project Targeted Activity "Linkages between Cryosphere Elements." Ralph Timmermann acknowledges funding by the Helmholtz Climate Initiative REKLIM (Regional Climate Change), a joint research project of the Helmholtz Association of German Research Centres (HGF). Matthew England is also supported by the Earth Science and Climate Change Hub of the Australian Government's National Environmental Science Programme (NESP) and the Centre for Southern Hemisphere Oceans Research (CSHOR), a joint research centre between QNLM, CSIRO, UNSW, and UTAS. Finally, John Klinck and two anonymous reviewers provided helpful comments on an earlier version of this manuscript.

\section{REFERENCES}

Agosta, C., X. Fettweis, and R. Datta, 2015: Evaluation of the CMIP5 models in the aim of regional modelling of the Antarctic surface mass balance. Cryosphere, 9, 2311-2321, https:// doi.org/10.5194/tc-9-2311-2015.

Arzeno, I. B., R. C. Beardsley, R. Limeburner, B. Owens, L. Padman, S. R. Springer, C. L. Stewart, and M. J. M. Williams, 2014: Ocean variability contributing to basal melt rate near the ice front of Ross Ice Shelf, Antarctica. J. Geophys. Res. Oceans, 119, 4214-4233, https://doi.org/10.1002/2014JC009792.

Bracegirdle, T. J., E. Shuckburgh, J.-B. Sallée, Z. Wang, A. J. S. Meijers, N. Bruneau, T. Phillips, and L. J. Wilcox, 2013: Assessment of surface winds over the Atlantic, Indian, and Pacific Ocean sectors of the Southern Ocean in CMIP5 models: Historical bias, forcing response, and state dependence. J. Geophys. Res. Atmos., 118, 547-562, https://doi.org/10.1002/jgrd.50153.

Cai, W., and Coauthors, 2014: Increasing frequency of extreme El Niño events due to greenhouse warming. Nat. Climate Change, 4, 111-116, https://doi.org/10.1038/nclimate2100.

Danilov, S., Q. Wang, R. Timmermann, N. Iakovlev, D. Sidorenko, M. Kimmritz, T. Jung, and J. Schröter, 2015: Finite-element sea ice model (FESIM), version 2. Geosci. Model Dev., 8, 1747-1761, https://doi.org/10.5194/gmd-8-1747-2015.

Dee, D. P., and Coauthors, 2011: The ERA-Interim reanalysis: Configuration and performance of the data assimilation system. Quart. J. Roy. Meteor. Soc., 137, 553-597, https://doi.org/ 10.1002/qj.828.

Dinniman, M. S., X. S. Asay-Davis, B. K. Galton-Fenzi, P. R. Holland, A. Jenkins, and R. Timmermann, 2016: Modeling ice shelf/ ocean interaction in Antarctica: A review. Oceanography, 29, 144-153, https://doi.org/10.5670/oceanog.2016.106.

Donat-Magnin, M., N. C. Jourdain, P. Spence, J. Le Sommer, H. Gallée, and G. Durand, 2017: Ice-shelf melt response to changing winds and glacier dynamics in the Amundsen Sea sector, Antarctica. J. Geophys. Res. Oceans, 122, $10206-10224$, https://doi.org/10.1002/2017JC013059.

Downes, S. M., and Coauthors, 2015: An assessment of Southern Ocean water masses and sea ice during 1988-2007 in a suite of interannual CORE-II simulations. Ocean Modell., 94, 67-94, https://doi.org/10.1016/j.ocemod.2015.07.022.

Dupont, T. K., and R. B. Alley, 2005: Assessment of the importance of ice-shelf buttressing to ice-sheet flow. Geophys. Res. Lett., 32, L04503, https://doi.org/10.1029/2004GL022024.
Dutrieux, P., and Coauthors, 2014: Strong sensitivity of Pine Island ice-shelf melting to climatic variability. Science, $\mathbf{3 4 3}, 174-178$, https://doi.org/10.1126/science.1244341.

Feldmann, J., and A. Levermann, 2015: Collapse of the West Antarctic ice sheet after local destabilization of the Amundsen Basin. Proc. Natl. Acad. Sci. USA, 112, 14191-14196, https:// doi.org/10.1073/pnas.1512482112.

Galton-Fenzi, B. K., 2009: Modelling ice-shelf/ocean interaction. Ph.D. thesis, University of Tasmania, $165 \mathrm{pp}$.

Gleckler, P. J., K. E. Taylor, and C. Doutriaux, 2008: Performance metrics for climate models. J. Geophys. Res., 113, D06104, https://doi.org/10.1029/2007JD008972.

Hattermann, T., and A. Levermann, 2010: Response of Southern Ocean circulation to global warming may enhance basal ice shelf melting around Antarctica. Climate Dyn., 35, 741-756, https://doi.org/10.1007/s00382-009-0643-3.

Hellmer, H. H., and D. J. Olbers, 1989: A two-dimensional model for the thermohaline circulation under an ice shelf. Antarct. Sci., 1, 325-336, https://doi.org/10.1017/S0954102089000490.

_ , F. Kauker, R. Timmermann, J. Determann, and J. Rae, 2012: Twenty-first-century warming of a large Antarctic ice-shelf cavity by a redirected coastal current. Nature, $\mathbf{4 8 5}, 225-228$, https://doi.org/10.1038/nature11064.

,,,--- and T. Hattermann, 2017: The fate of the southern Weddell Sea continental shelf in a warming climate. J. Climate, 30, 4337-4350, https://doi.org/10.1175/JCLI-D-16-0420.1.

Hogg, A. E., and G. H. Gudmundsson, 2017: Impacts of the Larsen-C ice shelf calving event. Nat. Climate Change, 7, 540542, https://doi.org/10.1038/nclimate3359.

Holland, D. M., and A. Jenkins, 1999: Modeling thermodynamic ice-ocean interactions at the base of an ice shelf. J. Phys. Oceanogr., 29, 1787-1800, https://doi.org/10.1175/1520-0485 (1999)029<1787:MTIOIA > 2.0.CO;2.

Jacobs, S. S., H. H. Hellmer, C. S. M. Doake, A. Jenkins, and R. M. Frolich, 1992: Melting of ice shelves and the mass balance of Antarctica. J. Glaciol., 38, 375-387, https://doi.org/ 10.1017/S0022143000002252.

— A. Jenkins, C. F. Giulivi, and P. Dutrieux, 2011: Stronger ocean circulation and increased melting under Pine Island glacier ice shelf. Nat. Geosci., 4, 519-523, https://doi.org/10.1038/ngeo1188.

Jenkins, A., P. Dutrieux, S. S. Jacobs, S. D. McPhail, J. R. Perrett, A. T. Webb, and D. White, 2010: Observations beneath Pine Island glacier in West Antarctica and implications for its retreat. Nat. Geosci., 3, 468-472, https://doi.org/10.1038/ ngeo890.

Kim, S.-J., and A. Stössel, 1998: On the representation of the Southern Ocean water masses in an ocean climate model. J. Geophys. Res., 103, 24 891-24 906, https://doi.org/10.1029/ 98JC02413.

Makinson, K., P. R. Holland, A. Jenkins, K. W. Nicholls, and D. M. Holland, 2011: Influence of tides on melting and freezing beneath Filchner-Ronne ice shelf, Antarctica. Geophys. Res. Lett., 38, L06601, https://doi.org/10.1029/ 2010GL046462.

Martin, T., and A. Adcroft, 2010: Parameterizing the fresh-water flux from land ice to ocean with interactive icebergs in a coupled climate model. Ocean Modell., 34, 111-124, https:// doi.org/10.1016/j.ocemod.2010.05.001.

Meier, W., F. Fetterrer, M. Savoie, S. Mallory, R. Duerr, and J. Stroeve, 2013: Climate data record of passive microwave sea ice concentration, version 2. NOAA/NSIDC: National Snow and Ice Data Center, accessed 3 February 2017, https://doi.org/ 10.7265/N55M63M1. 
Menemenlis, D., J.-M. Campin, P. Heimbach, C. Hill, T. Lee, A. Nguyen, M. Schodlok, and H. Zhang, 2008: ECCO2: High resolution global ocean and sea ice data synthesis. Mercator Ocean Quarterly Newsletter, No. 31, 13-21.

Mengel, M., and A. Levermann, 2014: Ice plug prevents irreversible discharge from East Antarctica. Nat. Climate Change, 4, 451-455, https://doi.org/10.1038/nclimate2226.

Merino, N., N. C. Jourdain, J. Le Sommer, H. Goosse, P. Mathiot, and G. Durand, 2018: Impact of increasing Antarctic glacial freshwater release on regional sea-ice cover in the Southern Ocean. Ocean Modell., 121, 76-89, https://doi.org/10.1016/ j.ocemod.2017.11.009.

Mueller, R. D., T. Hattermann, S. L. Howard, and L. Padman, 2018: Tidal influences on a future evolution of the FilchnerRonne ice shelf cavity in the Weddell Sea, Antarctica. Cryosphere, 12, 453-476, https://doi.org/10.5194/tc-12-453-2018.

Nakayama, Y., R. Timmermann, M. Schröder, and H. H. Hellmer, 2014: On the difficulty of modeling Circumpolar Deep Water intrusions onto the Amundsen Sea continental shelf. Ocean Modell., 84, 26-34, https://doi.org/10.1016/j.ocemod.2014.09.007.

Naud, C. M., J. F. Booth, and A. D. Del Genio, 2014: Evaluation of ERA-Interim and MERRA cloudiness in the Southern Ocean. J. Climate, 27, 2109-2124, https://doi.org/10.1175/JCLI-D-13-00432.1.

Naughten, K. A., K. J. Meissner, B. K. Galton-Fenzi, M. H. England, R. Timmermann, H. H. Hellmer, T. Hattermann, and J. B. Debernard, 2018: Intercomparison of Antarctic iceshelf, ocean, and sea-ice interactions simulated by MetROMSiceshelf and FESOM 1.4. Geosci. Model Dev., 11, 1257-1292, https://doi.org/10.5194/gmd-11-1257-2018.

Nicolas, J. P., and D. H. Bromwich, 2011: Precipitation changes in high southern latitudes from global reanalyses: A cautionary tale. Surv. Geophys., 32, 475-494, https://doi.org/10.1007/ s10712-011-9114-6.

Paolo, F. S., H. A. Fricker, and L. Padman, 2015: Volume loss from Antarctic ice shelves is accelerating. Science, 348, 327-331, https://doi.org/10.1126/science.aaa0940.

Rack, W., and H. Rott, 2004: Pattern of retreat and disintegration of the Larsen B ice shelf, Antarctic Peninsula. Ann. Glaciol., 39, 505-510, https://doi.org/10.3189/172756404781814005.

Rott, H., P. Skvarca, and T. Nagler, 1996: Rapid collapse of northern Larsen ice shelf. Antarct. Sci., 271, 788-792, https:// doi.org/10.1126/science.271.5250.788.

Sallée, J.-B., E. Shuckburgh, N. Bruneau, A. J. S. Meijers, T. J. Bracegirdle, and Z. Wang, 2013a: Assessment of Southern Ocean mixed-layer depths in CMIP5 models: Historical bias and forcing response. J. Geophys. Res. Oceans, 118, 18451862, https://doi.org/10.1002/jgrc.20157. of Southern Ocean water mass circulation and characteristics in CMIP5 models: Historical bias and forcing response. J. Geophys. Res. Oceans, 118, 1830-1844, https://doi.org/ 10.1002/jgrc.20135.

Sanford, T., P. C. Frumhoff, A. Luers, and J. Gulledge, 2014: The climate policy narrative for a dangerously warming world. Nat. Climate Change, 4, 164-166, https://doi.org/10.1038/nclimate2148.

Schmidtko, S., K. J. Heywood, A. F. Thompson, and S. Aoki, 2014: Multidecadal warming of Antarctic waters. Science, 346, 1227 1232, https://doi.org/10.1126/science.1256117.

Smith, J. A., and Coauthors, 2017: Sub-ice-shelf sediments record history of twentieth-century retreat of Pine Island glacier. Nature, 541, 77-80, https://doi.org/10.1038/nature20136.

Spence, P., S. M. Griffies, M. H. England, A. M. Hogg, O. A. Saenko, and N. C. Jourdain, 2014: Rapid subsurface warming and circulation changes of Antarctic coastal waters by poleward shifting winds. Geophys. Res. Lett., 41, 4601-4610, https://doi.org/ 10.1002/2014GL060613.

- R. M. Holmes, A. M. Hogg, S. M. Griffies, K. D. Stewart, and M. H. England, 2017: Localized rapid warming of West Antarctic subsurface waters by remote winds. Nat. Climate Change, 7, 595-603, https://doi.org/10.1038/nclimate3335.

Steig, E. J., Q. Ding, D. S. Battisti, and A. Jenkins, 2012: Tropical forcing of Circumpolar Deep Water inflow and outlet glacier thinning in the Amundsen Sea embayment, West Antarctica. Ann. Glaciol., 53, 19-28, https://doi.org/10.3189/2012AoG60A110.

Stewart, A. L., and A. F. Thompson, 2015: Eddy-mediated transport of warm Circumpolar Deep Water across the Antarctic shelf break. Geophys. Res. Lett., 42, 432-440, https://doi.org/ 10.1002/2014GL062281.

—, A. Klocker, and D. Menemenlis, 2018: Circum-Antarctic shoreward heat transport derived from an eddy- and tideresolving simulation. Geophys. Res. Lett., 45, 834-845, https:// doi.org/10.1002/2017GL075677.

Sun, S., S. L. Cornford, D. E. Gwyther, R. M. Gladstone, B. K. GaltonFenzi, L. Zhao, and J. C. Moore, 2016: Impact of ocean forcing on the Aurora Basin in the 21st and 22nd centuries. Ann. Glaciol., 57, 79-86, https://doi.org/10.1017/aog.2016.27.

Swart, N. C., and J. C. Fyfe, 2012: Observed and simulated changes in the Southern Hemisphere surface westerly wind-stress. Geophys. Res. Lett., 39, L16711, https://doi.org/10.1029/ 2012GL052810.

Taylor, K. E., R. J. Stouffer, and G. A. Meehl, 2012: An overview of CMIP5 and the experiment design. Bull. Amer. Meteor. Soc., 93, 485-498, https://doi.org/10.1175/BAMS-D-11-00094.1.

Timmermann, R., and H. H. Hellmer, 2013: Southern Ocean warming and increased ice shelf basal melting in the twentyfirst and twenty-second centuries based on coupled ice-ocean finite-element modelling. Ocean Dyn., 63, 1011-1026, https:// doi.org/10.1007/s10236-013-0642-0.

, and F. Kauker, 2014: Reducing the uncertainty in projections of future ice shelf basal melting. EGU General Assembly, Vienna, Austria, AWI, Vol. 16, EGU2014-7094, http:// meetingorganizer.copernicus.org/EGU2014/EGU2014-7094.pdf. , and S. Goeller, 2017: Response to Filchner-Ronne ice shelf cavity warming in a coupled ocean-ice sheet model-Part I: The ocean perspective. Ocean Sci., 13, 765-776, https://doi.org/ 10.5194/os-13-765-2017.

and Coauthors, 2010: A consistent dataset of Antarctic ice sheet topography, cavity geometry, and global bathymetry. Earth Syst. Sci. Data, 2, 261-273, https://doi.org/10.5194/ essd-2-261-2010.

- Q. Wang, and H. H. Hellmer, 2012: Ice-shelf basal melting in a global finite-element sea-ice/ice-shelf/ocean model. Ann. Glaciol., 53, 303-314, https://doi.org/10.3189/2012AoG60A156.

Turner, J., T. J. Bracegirdle, T. Phillips, G. J. Marshall, and J. S. Hosking, 2013: An initial assessment of Antarctic sea ice extent in the CMIP5 models. J. Climate, 26, 1473-1484, https://doi.org/ 10.1175/JCLI-D-12-00068.1.

Wang, Q., S. Danilov, D. Sidorenko, R. Timmermann, C. Wekerle, X. Wang, T. Jung, and J. Schröter, 2014: The Finite Element Sea Ice-Ocean Model (FESOM) v.1.4: Formulation of an ocean general circulation model. Geosci. Model Dev., 7, 663 693, https://doi.org/10.5194/gmd-7-663-2014.

Wunsch, C., P. Heimbach, R. M. Ponte, and I. Fukumori, 2009: The global general circulation of the ocean estimated by the ECCOConsortium. Oceanography, 22, 88-103, https://doi.org/10.5670/ oceanog.2009.41. 